\title{
Phytoplankton fuel the energy flow from zooplankton to small nekton in turbid mangrove waters
}

\author{
L. L. Chew ${ }^{1,2}$, V. C. Chong ${ }^{1,2, *}$, K. Tanaka ${ }^{3}$, A. Sasekumar ${ }^{1,2}$ \\ ${ }^{1}$ Institute of Biological Sciences, Faculty of Science, and ${ }^{2}$ Institute of Ocean and Earth Sciences, University of Malaya, \\ 50603 Kuala Lumpur, Malaysia \\ ${ }^{3}$ Japan International Research Center for Agricultural Sciences, 1-1 Ohwashi, Tsukuba, Ibaraki 350-8686, Japan
}

\begin{abstract}
Fish, zooplankton, seston, benthic microalgae and mangrove leaves were examined to investigate the trophic role of zooplankton in the food web of Matang estuaries. Despite the high turbidity and large amounts of detrital material in the water column, the study reveals that phytoplankton fuel the energy flow to zooplankton and small nekton in mangrove-fringed estuaries. The stable carbon isotope $\left(\delta^{13} \mathrm{C}\right)$ values and $\mathrm{C} / \mathrm{N}$ ratios $(7.2$ to 8.2$)$ of fine seston $(<63 \mu \mathrm{m})$ in estuaries indicate the importance of phytoplankton $\left(\delta^{13} \mathrm{C}:-22.8 \pm 0.6 \%\right.$ o to zooplankton $(-23.4$ to $-18.2 \%$ ) nutrition, with a trophic contribution of 70 to $84 \%$, whereas mangroves contributed $<11 \%$. In adjacent coastal waters, zooplankton $(-19.2$ to $-15.1 \%$ ) grazed on both phytoplankton and benthic diatoms $(-17.3 \pm 1.24 \%$ o). Aggregated or mucilage-secreting diatoms (giving depleted $\delta^{13} \mathrm{C}$ values) were abundant in the estuarine seston, but did not appear to be consumed or assimilated by zooplankton. Stomach content analysis showed significant consumption of zooplankton, especially copepods (mainly Pseudodiaptomus annandalei), sergestids (Acetes spp.) and mysids by young and small nekton ( $<14 \mathrm{~cm}$ standard length) in mangrove estuaries, while $\delta^{13} \mathrm{C}$ values indicate the increasing importance of mangrove carbon to juvenile fish nutrition (8 to $44 \%$ ). The range of $\delta^{15} \mathrm{~N}$ values from primary producers to small predatory fish indicates 4 trophic levels (excluding true piscivores) in Matang estuaries, with zooplankton at the second and third trophic level.
\end{abstract}

KEY WORDS: Stable isotopes - Stomach contents - Phytoplankton - Zooplankton - Nekton · Turbid mangrove waters

\section{INTRODUCTION}

Many marine fishes spawn in offshore waters and enter turbid mangrove estuaries at the larval or early juvenile stage (Laegdsgaard \& Johnson 2001, Blaber 2007, Ooi \& Chong 2011). Among the hypotheses advanced to explain why young fish enter mangrove habitats, the one on food supply has received the most attention (Nagelkerken et al. 2000, Laegdsgaard \& Johnson 2001, Chong 2007). Several studies have shown that high fish densities will generally correspond to high densities of planktonic and benthic animals (e.g. Jacoby \& Greenwood 1989, Edgar
\& Shaw 1995). Zooplankton are abundant in tropical mangrove estuaries (Robertson et al. 1988, Chew \& Chong 2011), which may explain why zooplanktonfeeding fish seem to dominate in mangrove fish communities (Blaber \& Blaber 1980, Robertson \& Duke 1987). It is apparent that mangrove estuaries also form zooplankton-rich ecosystems that could potentially be exploited by small fish as their source of energy. For instance, juvenile fish caught in Australian mangrove waters were found to feed primarily on copepods and brachyuran zoeae (Robertson \& Blaber 1992). In Matang mangrove estuaries, zooplankton, especially copepods and hyperbenthic 
shrimps, constituted a large proportion of the diet of young juvenile and small-sized fishes (Chew et al. 2007, Then 2008, Tanaka et al. 2011).

As mangrove detritus constitutes a large proportion of the organic matter in mangrove estuaries, there is a general perception that the estuarine food web is fueled by mangrove leaf carbon processed by both benthic micro- and macro-organisms (Odum \& Heald 1975, Robertson et al. 1992, Werry \& Lee 2005). However, the trophic pathway from mangrove detritus to higher consumers (particularly fishes) has become a contentious issue based on the recent findings from stable isotope studies (e.g. Fleming et al. 1990, Marguillier et al. 1997, Bouillon et al. 2000). Indeed, Robertson et al. (1992) alluded to phytoplankton and microphytobenthos providing substantially more energy than mangrove detritus to consumers in open mangrove waterways. Although several experimental and field observations have indicated ingestion and assimilation of vascular plant detritus by zooplankton (DeMott 1988, McKinnon \& Klumpp 1998) and juvenile decapods (Newell et al. 1995, Dittel et al. 2000, Schwamborn et al. 2006), these studies also indicate that, given the choice, they would prefer live food.

Senescent mangrove leaf litter may be unattractive as food to most animals because it is nutritionally poor (high $\mathrm{C} / \mathrm{N}$ ratio), not easily digestible and high in tannins (Wolcott \& O'Connor 1992). An exception is found in the grapsid crabs in mangrove forests which shred and consume leaf litter and subsequently defecate bacterial-laden faecal pellets that serve as potential food for both benthic and pelagic consumers (Robertson \& Daniel 1989, Werry \& Lee 2005). In fact, the aforementioned authors showed that experimentally fed planktonic copepods assimilated and survived better when offered such faecal pellets as compared to microalgae.

Despite the general acceptance that mangrove zooplankton support fish nutrition, either directly or indirectly via trophic links, there is a lack of in-depth understanding of the trophodynamics involved, particularly that which relates to the carbon source(s) and its flow through the mangrove food web. While the approach of stable isotope analysis has frequently been used to trace the carbon source of consumers in tropical mangrove ecosystems, few studies relate to zooplankton (e.g. Bouillon et al. 2000, Schwamborn et al. 2002). Most studies have considered bulk zooplankton without quantifying the importance of component species to the food web.

Previous stable isotope studies in Malaysian mangroves and estuarine waters have focused mainly on the communities of demersal fish, prawns and intertidal macrobenthos (Rodelli et al. 1984, Newell et al. 1995, Hayase et al. 1999, Chong et al. 2001), but no study pertains to zooplankton. This is unfortunate because the reasons for not focusing more on the pelagic column are partly due to the general acceptance of a detritus-energy pathway and that phytoplankton would play a lesser role in turbid water systems, and to the constraints in isolating and identifying zooplankton taxa. In a review of mangrove ecosystem functions, Chong (2007) provided some evidence of the contribution of phytoplankton to the trophodynamics of the largest mangrove forest in Peninsular Malaysia based on the large expanse of open water in the lower Matang estuary, high chlorophyll a concentration and high consumption of planktonic fauna by mangrove fishes. He hypothesized that most juvenile mangrove fish shift their diet preference ontogenetically from one that is initially phytoplankton based to one that is detritus based. Such a hypothesis is not plausible if zooplankton (mainly copepods, mysids and Acetes shrimps) feed on suspended mangrove detrital particles rather than phytoplankton, given the high concentrations of mangrove detritus reported in the seston (Hayase et al. 1999).

The present study thus tests the hypothesis that phytoplankton, not mangrove detritus, is the main carbon source for zooplankton species in Matang mangrove estuaries, and evaluates the trophic contribution of zooplankton to the nutrition of juvenile and small-sized fishes in turbid mangrove waters. We used dual stable elemental isotope analysis of producers and consumers, corroborated by fish stomach content analysis, to address the objectives.

\section{MATERIALS AND METHODS}

\section{Study area}

The study site was located at the Matang Mangrove Forest Reserve (MMFR) on the west coast of Peninsular Malaysia (Fig. 1). The MMFR covers a total of 41711 ha and has been sustainably managed as a productive forest since 1905. The water depths in the estuaries are relatively shallow, averaging $5 \mathrm{~m}$, with a maximum depth of $10 \mathrm{~m}$. The tidal regime is semidiurnal, and mean tidal levels at MHWS, MHWN, MLWN and MLWS (mean high/low water at neap/spring tide) were 2.1, 1.5, 0.9 and $0.3 \mathrm{~m}$ above chart datum (National Hydrographic Centre 2002). Mean salinity, which ranged from 20.4 to $30.5 \mathrm{ppt}$, increased gradually from the upper estuary $(7 \mathrm{~km}$ 
Fig. 1. Location of sampling stations in Matang mangrove estuaries (SP, SL, SB, SK) and in nearshore (NS) and offshore (OS) waters. Sampling sites for stable isotope analysis are: $(*)$ seston; $(\bullet)$ zooplankton; $(\mathbf{X})$ fish;

(^) stomach content analysis

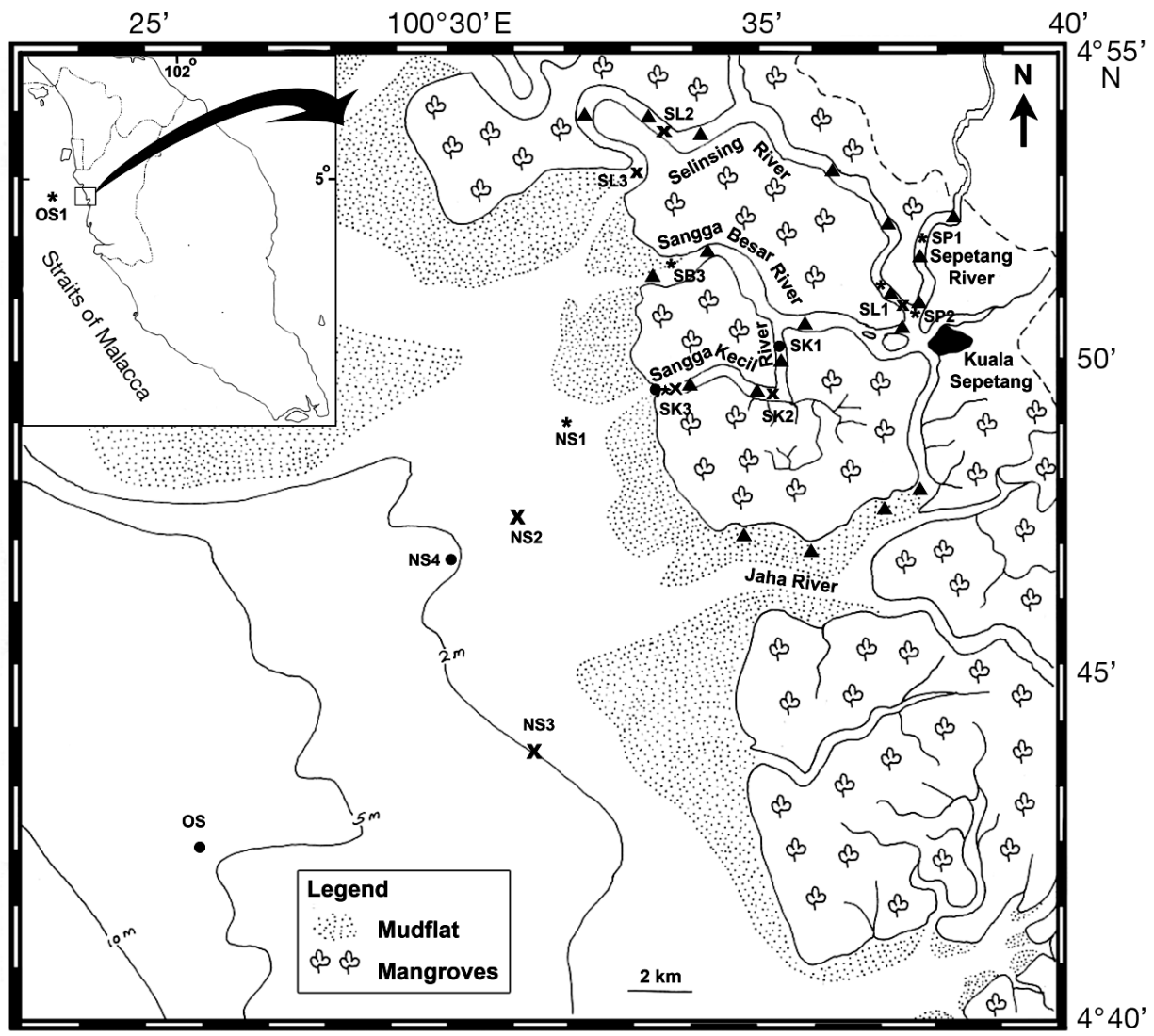

upstream) to $16 \mathrm{~km}$ offshore. Turbidity was higher in the estuary $(32.1 \pm 52.7$ nephelometer turbidity units [NTU]) and nearshore waters (28.5 \pm 22.5 NTU) compared to offshore waters $(15.2 \pm 14.3 \mathrm{NTU})$, with corresponding mean chlorophyll a concentrations of 21.3, 12.3 and $9.2 \mu \mathrm{g}^{-1}$, respectively (Chew \& Chong 2011). The authors also reported high temporal variability, with significantly higher chlorophyll a concentrations during the wet $\left(21.3 \mu^{-1}\right)$ than during the dry $\left(14.1 \mu^{-1}\right)$ period, with the maximum concentration exceeding $80 \mu \mathrm{g} \mathrm{l}^{-1}$.

\section{Field collection}

Samples of fish, zooplankton, seston and senescent mangrove leaves were collected and analyzed between June 2003 and June 2011. For analysis of fish stomach contents, juvenile and small-sized fishes were sampled monthly over a 12 mo period near the banks of the Sangga Kecil, Sangga Besar, Sepetang, Selinsing and Jaha Rivers (i.e. estuaries) (Fig. 1). Collections were made at Stns SL1 $\left(4^{\circ} 51^{\prime} \mathrm{N}, 100^{\circ} 37^{\prime} \mathrm{E}\right)$, SL2 ( $\left.4^{\circ} 54^{\prime} \mathrm{N}, 100^{\circ} 34^{\prime} \mathrm{E}\right)$ and SL3 (4 $\left.{ }^{\circ} 53^{\prime} \mathrm{N}, 100^{\circ} 33^{\prime} \mathrm{E}\right)$ in the Selinsing River; Stns SK2 $\left(4^{\circ} 49^{\prime} \mathrm{N}, 100^{\circ} 35^{\prime} \mathrm{E}\right)$ and SK3 $\left(4^{\circ} 49^{\prime} \mathrm{N}, 100^{\circ} 33^{\prime} \mathrm{E}\right)$ in the Sangga Kecil
River; and Stns NS2 $\left(4^{\circ} 47.5^{\prime} \mathrm{N}, 100^{\circ} 31^{\prime} \mathrm{E}\right)$ and NS3 $\left(4^{\circ} 43^{\prime} \mathrm{N}, 100^{\circ} 31^{\prime} \mathrm{E}\right.$ ) in nearshore waters (ca. $7 \mathrm{~km}$ offshore) (Fig. 1).

Drifting senescent mangrove leaves were collected at Stns SK1 ( $\left.4^{\circ} 50^{\prime} \mathrm{N}, 100^{\circ} 35^{\prime} \mathrm{E}\right), \mathrm{SK} 2$ and SK3 in the Sangga Kecil River using a scoop net. Zooplankton samples were collected by oblique tows using $45 \mathrm{~cm}$ diameter bongo nets $(180 \mu \mathrm{m})$ at Stns SK1 and SK3 in the Sangga Kecil River, Stn NS4 (4 46.8' N, $\left.100^{\circ} 2^{\prime} 9^{\prime} \mathrm{E}\right)$ in nearshore waters (8 $\mathrm{km}$ offshore) and Stn OS $\left(4^{\circ} 42^{\prime} \mathrm{N}, 100^{\circ} 25^{\prime} \mathrm{E}\right)$ in offshore waters (18 km offshore). Collected samples of zooplankton were individually screened through 1000, 500 and $250 \mu \mathrm{m}$ Endecott sieves with filtered seawater on deck. Fractionated zooplankton samples were then transferred into separate sample bottles for further sorting in the laboratory.

Seston samples were collected using a Van Dorn sampler at 7 stations SP1 $\left(4^{\circ} 52^{\prime} \mathrm{N}, 100^{\circ} 37.8^{\prime} \mathrm{E}\right), \mathrm{SP} 2$ $\left(4^{\circ} 51^{\prime} \mathrm{N}, 100^{\circ} 37^{\prime} \mathrm{E}\right), \mathrm{SL} 1, \mathrm{SB} 3\left(4^{\circ} 51.5^{\prime} \mathrm{N}, 100^{\circ} 33.5^{\prime} \mathrm{E}\right)$, SK3, NS1 $\left(4^{\circ} 49^{\prime} \mathrm{N}, 100^{\circ} 31^{\prime} \mathrm{E}\right)$ and OS1 $\left(4^{\circ} 48^{\prime} \mathrm{N}\right.$, $100^{\circ} 03^{\prime} \mathrm{E}$ ) located in the upper part of the estuary to $55 \mathrm{~km}$ offshore (Fig. 1). Four litres of seawater from the estuary and nearshore stations were pre-filtered through a $63 \mu \mathrm{m}$ mesh size plankton net in the field to remove zooplankton before further filtration through 
pre-combusted GF/C Whatman glass microfiber filter papers in the laboratory (Newell et al. 1995). Additional pre-filtered samples at SP1, SL1 and SB3 were preserved in $4 \%$ buffered formalin for microscopic examination of their constituents. About 501 of seawater from the far offshore station OS1 were similarly filtered on board a ship. Seston retained on the filter paper was thoroughly rinsed with distilled water several times and then transferred into individual screw-capped containers.

All other collected field samples were kept on ice in an ice-chest on board the boat, but kept frozen at $-20^{\circ} \mathrm{C}$ in the laboratory until subsequent analysis.

\section{Laboratory procedures}

\section{Stable isotope analysis}

Frozen zooplankton samples were thawed and sorted to the lowest taxon. The sorted sample of each taxon was placed on a precombusted filter paper, rinsed thoroughly with distilled water, and then oven dried to obtain at least $2 \mathrm{mg}$ dry weight of tissues. Senescent mangrove leaves were also thoroughly rinsed with distilled water before being dried in the oven.

Six representative and major zooplanktivorous species that made up $35 \%$ of the total density of 94 fish species sampled in Matang mangrove estuaries (Chew et al. 2007, Then 2008) were selected for stable isotope analysis; these were juvenile and adult Stolephorus baganensis (1.4\%) and Thryssa kammalensis (1.4\%), and young juveniles of Arius maculatus (22\%), Leiognathus brevirostris (3.7\%), Johnius weberi $(6.2 \%)$ and Upeneus sulphureus (0.5\%). Fish muscle tissues were dissected and rinsed thoroughly with distilled water. Tissue muscles of the same species and from the same trawl were pooled together as 1 sample for stable isotope analysis.

All samples for stable isotope analysis were oven dried at $70^{\circ} \mathrm{C}$ for $3 \mathrm{~d}$. Dried samples were cooled in a desiccator, sealed in individual plastic bags before they were sent to the University of Waikato, New Zealand, and, later, to the Marine Biological Laboratory, Wood Hole, USA, for stable isotopic carbon and nitrogen analyses.

The dried samples were ground to a fine powder before they were combusted to $\mathrm{N}_{2}$ and $\mathrm{CO}_{2}$ gasses by Europa ANCA-SL (automated nitrogen carbon analysis for solids and liquids) elemental analyzer. Only samples from ostracods were acid treated before the combustion. The stable isotope carbon and nitrogen ratios were determined by a Europa 20-20 mass spec- trometer. Results were expressed in standard $\delta$ notation, and values were determined based on the following equations:

$$
\begin{aligned}
\delta^{13} \mathrm{C}_{1} \% \text { o } & =\left[\left({ }^{13} \mathrm{C} /{ }^{12} \mathrm{C}\right)_{\text {sample }} /\left({ }^{13} \mathrm{C} /{ }^{12} \mathrm{C}\right)_{\text {standard, PDB }}-1\right] \\
& \times 1000 \\
\delta^{15} \mathrm{~N}, \% \text { o } & =\left[\left({ }^{15} \mathrm{~N} /{ }^{14} \mathrm{~N}\right)_{\text {sample }} /\left({ }^{15} \mathrm{~N} /{ }^{14} \mathrm{~N}\right)_{\text {standard, air }}-1\right] \\
& \times 1000
\end{aligned}
$$

The standard reference materials for carbon and nitrogen in stable isotope analysis were Peedee Belemnite (PDB) and $\mathrm{N}_{2}$ in air, respectively. The precision of the spectrophotometer was $\pm 0.1 \%$ for both measurements of $\delta^{15} \mathrm{~N}$ and $\delta^{13} \mathrm{C}$.

\section{Seston examination}

Percentage volumetric composition of fine constituents was estimated using the eye-estimation method with the aid of a $20 \times 20$ grid eyepiece micrometer (Chong 1977) under an inverted compound microscope. Scanning electron microscopy (SEM) of seston materials prepared using the critical point drying technique was used to further examine small aggregated cells. The aggregating substances suspected to be or related to mucopolysaccharides were tested by staining the cell samples with Alcian Blue $\mathrm{pH}$ 2.5. Further samples were treated with hydrogen peroxide or dichromic acid to remove organic matter before viewing under the light microscope.

\section{Analysis of fish stomach contents}

Juvenile or small-sized fish $(<14 \mathrm{~cm})$, belonging to 26 predominant species, were examined for their stomach contents. The examined fish species made up $87.6 \%$ of the mean fish abundance of 3280 ind. ha $^{-1}$ reported for Matang estuaries (Then 2008). Food or prey items were examined under a microscope, and their volumes were estimated with the aid of a $10 \times 10$ grid eyepiece micrometer. Food or prey items were identified and enumerated to the lowest taxonomic level. A total of 2521 fish stomachs were analyzed, of which 2183 stomachs were found to contain food.

\section{Data analysis}

Trophic level of consumers

$\delta^{15} \mathrm{~N}$ values of consumers across stations were averaged for each taxon to determine the trophic position 
of zooplankton and fish in the Matang mangrove food web. Trophic position was assigned based on the method described in Vander Zanden \& Rasmussen (1999):

Trophic position consumer $=2+\left[\left(\delta^{15} \mathrm{~N}_{\text {consumer }}-\delta^{15} \mathrm{~N}_{\text {base }}\right)\right.$ $\left.\left(\Delta \delta^{15} \mathrm{~N}\right)^{-1}\right]$

where $\delta^{15} \mathrm{~N}_{\text {consumer }}$ is the $\delta^{15} \mathrm{~N}$ value for a given consumer, $\delta^{15} \mathrm{~N}_{\text {base }}$ is the value of a representative baseline at Trophic Position 2 and $\Delta \delta^{15} \mathrm{~N}$ is the trophic fractionation value. The herbivorous copepod Pseudodiaptomus, with the second lowest $\delta^{15} \mathrm{~N}$ value, was used as the baseline at Trophic Position 2. Although brachyuran zoeae had the lowest mean $\delta^{15} \mathrm{~N}$ values, they were not assigned as the representative baseline as a precaution because during embryogenesis their larvae are known to be very depleted in $\delta^{15} \mathrm{~N}$ value relative to their parental adults (Schwamborn et al. 2002).

Relative contribution of primary sources to consumers' nutrition

The proportional contribution of mangroves, phytoplankton and benthic diatoms to the nutrition of zooplankton and small nekton was estimated using the Stable Isotope Analysis in R (SIAR) package (Parnell et al. 2010). Prior to SIAR, isotopic signatures of zooplankton were adjusted for trophic fractionation based on the following equation:

$$
\delta X_{\text {adjzoo }}=\delta X_{\mathrm{zoo}}-\left(\mathrm{TL}_{\mathrm{zoo}}-1\right) \Delta \delta X_{\mathrm{zoo}}
$$

where $\delta X_{\text {adjzoo }}$ is the adjusted zooplankton $\delta^{13} \mathrm{C}$ or $\delta^{15} \mathrm{~N}$ value, $\delta X_{\text {zoo }}$ is the initial zooplankton $\delta^{13} \mathrm{C}$ or $\delta^{15} \mathrm{~N}$ value, $\mathrm{TL}_{\mathrm{zoo}}$ is the assigned trophic level of zooplankton in the Matang food web and $\Delta \delta X_{\mathrm{zoo}}$ is the trophic fractionation value for zooplankton $\left(\Delta \delta^{13} \mathrm{C}=\right.$ $0.5 \%$ and $\Delta \delta^{15} \mathrm{~N}=2 \%$ ). For zooplanktivorous fish, the isotopic signatures were adjusted based on the following equation:

$$
\delta X_{\text {adjish }}=\delta X_{\text {fish }}-\left[\left(\mathrm{TL}_{\text {fish }}-2\right) \Delta \delta X_{\text {zoo }}+\Delta \delta X_{\text {fish }}\right]
$$

where $\delta X_{\text {adjish }}$ is the adjusted fish $\delta^{13} \mathrm{C}$ or $\delta^{15} \mathrm{~N}$ value, $\delta X_{\text {fish }}$ is the initial fish $\delta^{13} \mathrm{C}$ or $\delta^{15} \mathrm{~N}$ value, $\mathrm{TL}_{\text {fish }}$ is the assigned trophic level of fish in the Matang food web, $\Delta \delta X_{\text {zoo }}$ is as stated above and $\Delta \delta X_{\text {fish }}$ is the trophic fractionation value for fish $\left(\Delta \delta^{13} \mathrm{C}=0.5 \%\right.$ and $\Delta \delta^{15} \mathrm{~N}=3 \%$ ).

A stepwise adjustment of isotopic enrichment between 2 trophic levels in the present study was applied based on published literature and present data. A $\Delta \delta^{13} \mathrm{C}$ of $0.5 \%$ between all trophic levels
(Vander Zanden \& Rasmussen, 2001) and a $\Delta \delta^{13} \mathrm{~N}$ of $2 \%$ between the first and second trophic levels (McCutchan et al. 2003) were adopted in the present study. Based on our data, however, we adopted a $\Delta \delta^{15} \mathrm{~N}$ of $2 \%$ for zooplankton between the second and third trophic levels and of $3 \%$ for fish between the third and fourth trophic levels. These 2 values have also been reported by other workers (Peterson \& Fry 1987, Vander Zanden \& Rasmussen 2001, McCutchan et al. 2003). Adjusted zooplankton and fish isotopic signatures were pooled according to 3 locations (i.e. estuary, river mouth and adjacent coastal waters) before computations on SIAR.

Univariate analysis

Mean $\delta^{13} \mathrm{C}$ and $\delta^{15} \mathrm{~N}$ values of seston were statistically tested using 1-way ANOVA (factor: location), followed by Tukey's honestly significant difference (HSD) test if the ANOVA test was significant. To test whether sampling location had a significant influence on zooplankton $\delta^{13} \mathrm{C}$ values, data were first pooled according to trophic position before the nonparametric Kruskal-Wallis test was applied. Significance level for all statistical tests was set at $\alpha=0.05$. All statistical tests were carried out using the STATISTICA Ver.10 software.

Fish stomach contents analysis

Principal component analysis (PCA) was used to explore the diet preference of the 26 selected fish species found in the Matang mangrove estuaries using the CANOCO 4.5 software. To apply this procedure, the percentage volume of food item was averaged according to fish species. Averaged data were arcsine transformed before they were subjected to PCA. Results of PCA were depicted by a 2-dimensional ordination biplot diagram.

\section{RESULTS}

\section{Stable isotope analysis}

Mangrove leaves and seston

Senescent mangrove leaves had overall mean $( \pm \mathrm{SD})$ values of $-28.3 \%$ o $( \pm 0.9)$ for $\delta^{13} \mathrm{C}, 4.1 \%$ o $( \pm 1.8)$ for $\delta^{15} \mathrm{~N}$ and $148.5( \pm 54.4)$ for $\mathrm{C} / \mathrm{N}$ ratio (Table 1). Seston $(<63 \mu \mathrm{m})$ samples from the upper estuary had a lower 
Table 1. Mean $( \pm \mathrm{SD})$ values of $\delta^{13} \mathrm{C}(\%), \delta^{15} \mathrm{~N}(\%)$ and $\mathrm{C} / \mathrm{N}$ ratios for samples collected in Matang mangrove estuaries and adjacent coastal waters, Malaysia. Stations, see Fig. 1. n: sample size; number within parentheses: number of individuals pooled for analysis; -: data not available; SL: standard length $(\mathrm{cm})$

\begin{tabular}{|c|c|c|c|c|c|c|c|c|c|}
\hline \multirow[t]{2}{*}{ Species/type } & \multirow[t]{2}{*}{ Station } & \multirow[t]{2}{*}{$\mathrm{n}$} & \multirow{2}{*}{$\begin{array}{c}\text { Size } \\
\text { category }\end{array}$} & \multicolumn{2}{|c|}{$\delta^{13} \mathrm{C}$} & \multicolumn{2}{|c|}{$\delta^{15} \mathrm{~N}$} & \multicolumn{2}{|c|}{$\mathrm{C} / \mathrm{N}$} \\
\hline & & & & Mean & $\pm \mathrm{SD}$ & Mean & $\pm \mathrm{SD}$ & Mean & $\pm \mathrm{SD}$ \\
\hline \multicolumn{10}{|l|}{ Scenescent mangrove leaf } \\
\hline Rhizophora mucronata & SK1 & 2 & & -28.0 & 1.2 & 6.3 & 0.5 & 115.4 & 42.4 \\
\hline Rhizophora apiculata & SK2 & 2 & & -27.9 & 0.9 & 2.3 & 0.0 & 116.2 & 2.9 \\
\hline Bruguiera parviflora & SK3 & 2 & & -29.0 & 0.8 & 3.8 & 0.5 & 214.0 & 9.3 \\
\hline Mean & & & & -28.3 & 0.9 & 4.1 & 1.8 & 148.5 & 54.4 \\
\hline \multicolumn{10}{|l|}{ Seston } \\
\hline & SP1 & 2 & $<63 \mu \mathrm{m}$ & -26.1 & 0.1 & 6.1 & 0.2 & 8.2 & 0.1 \\
\hline & SP2 & 3 & $<63 \mu \mathrm{m}$ & -26.6 & 0.5 & 4.1 & 1.0 & 8.1 & 0.3 \\
\hline & SL1 & 2 & $<63 \mu \mathrm{m}$ & -26.9 & 0.2 & 7.2 & 0.8 & 8.0 & 0.2 \\
\hline & SB3 & 2 & $<63 \mu \mathrm{m}$ & -25.2 & 0.2 & 8.4 & 0.1 & 7.2 & 0.2 \\
\hline & SK3 & 3 & $<63 \mu \mathrm{m}$ & -22.8 & 0.6 & 7.5 & 0.7 & 7.9 & 0.1 \\
\hline & NS1 & 3 & $<63 \mu \mathrm{m}$ & -18.8 & 2.2 & 4.9 & 1.2 & 8.3 & 0.3 \\
\hline & OS1 & 3 & $<63 \mu \mathrm{m}$ & -22.7 & 0.4 & 8.5 & 0.1 & 7.7 & 1.0 \\
\hline \multicolumn{10}{|l|}{ Copepoda } \\
\hline Acartia spinicauda & SK1 & 2 & $>500 \mu \mathrm{m}$ & -22.3 & 0.2 & 8.8 & 0.1 & 5.3 & 0.2 \\
\hline A. spinicauda & SK3 & 2 & $>500 \mu \mathrm{m}$ & -20.6 & 0.5 & 9.0 & 0.3 & 5.7 & 0.2 \\
\hline Centropages dorsispinatus & SK3 & 2 & $>500 \mu \mathrm{m}$ & -20.0 & 0.4 & 8.1 & 0.3 & 5.5 & 0.2 \\
\hline C. dorsispinatus & OS & 2 & $>500 \mu \mathrm{m}$ & -17.6 & 0.1 & 8.1 & 0.1 & 5.0 & 0.1 \\
\hline Pseudiaptomus spp. & SK1 & 2 & $>500 \mu \mathrm{m}$ & -21.5 & 0.4 & 7.8 & 0.1 & 5.4 & 0.1 \\
\hline Pseudiaptomus spp. & SK3 & 2 & $>500 \mu \mathrm{m}$ & -20.1 & 0.1 & 8.1 & 0.1 & 5.6 & 0.1 \\
\hline Pseudiaptomus spp. & OS & 2 & $>500 \mu \mathrm{m}$ & -17.8 & 0.1 & 7.0 & 0.1 & 5.1 & 0.2 \\
\hline Tortanus spp. & SK1 & 2 & $>500 \mu \mathrm{m}$ & -22.7 & 0.0 & 10.2 & 0.4 & 5.2 & 0.2 \\
\hline Tortanus spp. & SK3 & 2 & $>500 \mu \mathrm{m}$ & -20.6 & 0.6 & 8.9 & 0.2 & 5.7 & 0.1 \\
\hline Tortanus spp. & OS & 2 & $>500 \mu \mathrm{m}$ & -18.1 & 0.1 & 9.0 & 0.4 & 4.9 & 0.0 \\
\hline \multicolumn{10}{|l|}{ Decapoda } \\
\hline Acetes spp. & SK1 & 2 & $>500 \mu \mathrm{m}$ & -20.0 & 0.5 & 9.9 & 0.7 & 5.1 & 0.6 \\
\hline Acetes spp. & NS4 & 2 & $>500 \mu \mathrm{m}$ & -16.1 & 0.1 & 9.6 & 0.7 & 4.6 & 0.2 \\
\hline Brachyuran zoeae & SK3 & 2 & $>500 \mu \mathrm{m}$ & -20.0 & 1.1 & 5.8 & 0.1 & 9.3 & 0.5 \\
\hline Brachyuran zoeae & NS4 & 2 & $>500 \mu \mathrm{m}$ & -19.2 & 0.0 & 4.3 & 0.2 & 12.3 & 0.9 \\
\hline Caridean zoeae & SK3 & 2 & $>500 \mu \mathrm{m}$ & -20.3 & 0.9 & 8.2 & 0.0 & 5.9 & 0.1 \\
\hline Diogenidae zoeae & OS & 2 & $>500 \mu \mathrm{m}$ & -18.0 & 0.4 & 8.5 & 0.5 & 6.8 & 0.3 \\
\hline Lucifer hanseni & OS & 3 & $>500 \mu \mathrm{m}$ & -17.7 & 0.4 & 8.4 & 0.1 & 5.8 & 0.3 \\
\hline Porcellanidae zoeae & SK1 & 3 & $>500 \mu \mathrm{m}$ & -19.0 & 0.1 & 8.6 & 0.1 & 6.2 & 0.3 \\
\hline Porcellanidae zoeae & NS4 & 3 & $>500 \mu \mathrm{m}$ & -15.1 & 0.2 & 7.7 & 0.1 & 6.5 & 0.3 \\
\hline \multicolumn{10}{|l|}{ Other zooplankton } \\
\hline Mysidae & SK1 & 2 & $>500 \mu \mathrm{m}$ & -20.5 & 0.4 & 10.8 & 0.2 & 4.7 & 0.3 \\
\hline Mysidae & NS4 & 2 & $>500 \mu \mathrm{m}$ & -16.5 & 0.6 & 10.5 & 0.3 & 4.8 & 0.3 \\
\hline Ostracoda & SK1 & 2 & $>500 \mu \mathrm{m}$ & -18.2 & 1.3 & 8.9 & 0.1 & 9.4 & 0.4 \\
\hline Stomatopoda larvae & SK1 & 2 & $>500 \mu \mathrm{m}$ & -21.2 & 0.1 & 11.0 & 0.1 & 6.0 & 0.3 \\
\hline Stomatopoda larvae & NS4 & 2 & $>500 \mu \mathrm{m}$ & -17.3 & 0.2 & 9.1 & 0.2 & 5.9 & 0.5 \\
\hline Chaetognatha & SK1 & 3 & $>500 \mu \mathrm{m}$ & -23.4 & 0.1 & 11.7 & 0.1 & 11.7 & 0.3 \\
\hline Chaetognatha & OS & 2 & $>500 \mu \mathrm{m}$ & -18.9 & 0.4 & 11.3 & 0.1 & 7.4 & 0.7 \\
\hline \multicolumn{10}{|l|}{ Fish } \\
\hline Arius maculatus & SL2 & $2(6,2$ & $6-10.1 \mathrm{~cm} \mathrm{SL}$ & -23.8 & 0.0 & 12.7 & 0.1 & - & - \\
\hline Johnius weberi & NS2 & $2(3,3$ & $.4-9.3 \mathrm{~cm} \mathrm{SL}$ & -18.0 & 1.4 & 12.8 & 0.1 & - & - \\
\hline J. weberi & SK3 & $2(3,3$ & $.5-9.0 \mathrm{~cm} \mathrm{SL}$ & -20.7 & 2.4 & 13.0 & 0.2 & - & - \\
\hline J. weberi & SL3 & $2(2,2$ & $.1-9.5 \mathrm{~cm} \mathrm{SL}$ & -24.5 & 1.0 & 12.6 & 0.4 & - & - \\
\hline J. weberi & SL1 & $2(3,2$ & $.2-8.8 \mathrm{~cm} \mathrm{SL}$ & -23.3 & 1.9 & 13.7 & 0.5 & - & - \\
\hline Leiognathus brevirostris & SK2 & $2(4,4$ & $.0-4.5 \mathrm{~cm} \mathrm{SL}$ & -24.1 & 0.4 & 13.6 & 0.2 & - & - \\
\hline L. brevirostris & SL2 & $2(7,6$ & $1-4.9 \mathrm{~cm} \mathrm{SL}$ & -24.8 & 0.3 & 12.6 & 0.5 & - & - \\
\hline L. brevirostris & SL1 & $2(5,5$ & $8-4.5 \mathrm{~cm} \mathrm{SL}$ & -24.8 & 0.1 & 14.2 & 0.0 & - & - \\
\hline Stolephorus baganensis & NS2 & $2(5,4$ & $.2-6.9 \mathrm{~cm} \mathrm{SL}$ & -16.7 & 0.6 & 13.2 & 0.0 & - & - \\
\hline S. baganensis & SK2 & $2(5,6$ & $.5-6.8 \mathrm{~cm} \mathrm{SL}$ & -20.6 & 0.9 & 14.7 & 0.4 & - & - \\
\hline S. baganensis & SL3 & $2(1,1$ & $.1-6.3 \mathrm{~cm} \mathrm{SL}$ & -21.8 & 0.3 & 13.3 & 0.5 & - & - \\
\hline Thryssa kammalensis & NS3 & $2(2,3$ & $0-6.5 \mathrm{~cm} \mathrm{SL}$ & -17.7 & 1.3 & 13.6 & 0.6 & - & - \\
\hline T. kammalensis & SK2 & $2(4,1$ & $.3-8.2 \mathrm{~cm} \mathrm{SL}$ & -19.0 & 0.1 & 13.9 & 0.2 & - & - \\
\hline T. kammalensis & SL3 & $2(1,1$ & $.3-5.5 \mathrm{~cm} \mathrm{SL}$ & -22.9 & 1.4 & 13.1 & 0.1 & - & - \\
\hline T. kammalensis & SL1 & $2(3,3$ & $.6-9.2 \mathrm{~cm} \mathrm{SL}$ & -20.4 & 0.2 & 14.7 & 0.1 & - & - \\
\hline Upeneus sulphureus & NS3 & $2(4,2$ & $.5-6.5 \mathrm{~cm} \mathrm{SL}$ & -15.8 & 0.1 & 11.7 & 0.1 & - & - \\
\hline
\end{tabular}


Table 2. Results of 1-way ANOVA and post hoc Tukey honestly significant difference (HSD) tests on seston $\delta^{13} \mathrm{C}$ and $\delta^{15} \mathrm{~N}$ values, with comparisons among stations. Homogeneous groups are underlined. ${ }^{* * *} \mathrm{p}<0.001 ;{ }^{* *} \mathrm{p}<0.01$; stations, see Fig. 1

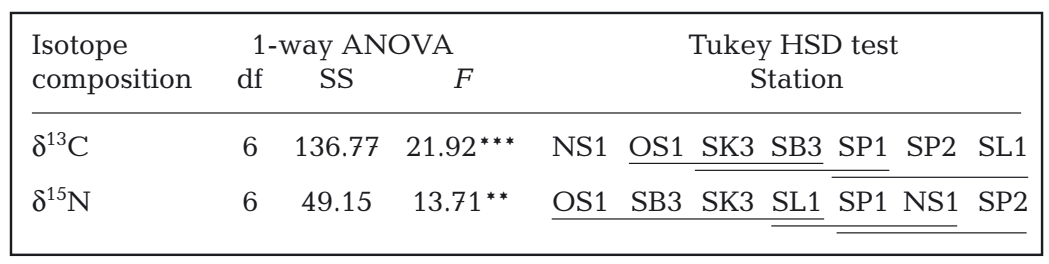

$\delta^{13} \mathrm{C}$ signature in the study area, and was subsequently adopted as the source signature in the mixing model. The seston $\delta^{15} \mathrm{~N}$ values were significantly lower at SP2 (4.1 $\pm 1 \%$ o) and NS1 $(4.9 \pm 1.2 \%)$ compared to those at SK3 $(7.5 \pm 0.7 \%)$, SB3 $(8.4 \pm 0.1 \%$ ) and OS1 (8.5 $\pm 0.1 \%$ o) (ANOVA, p < 0.01 ; Tables $1 \& 2$ ). The $\mathrm{C} / \mathrm{N}$ ratios for all seston samples were very much lower than for senescent mangrove mean $\delta^{13} \mathrm{C}$ value at SP1 $(-26.1 \pm 0.1 \%)$, SP2 (-26.6 \pm $0.5 \%$ ) and SL1 $(-26.9 \pm 0.2 \%$, which is close to the mangrove carbon signature. The mean seston $\delta^{13} \mathrm{C}$ values at the nearshore station NS1 $(-18.8 \pm 2.2 \%$ ) were significantly the most enriched values relative to seston samples collected at other stations (ANOVA, p < 0.001, Tables $1 \& 2$ ). The surface seston samples collected at the farthest offshore station, OS1, had a mean $\delta^{13} \mathrm{C}$ value of $-22.7 \%$ o $( \pm 0.4)$ which was almost identical to the value recorded at the river mouth station (SK3: $-22.8 \%$ ). Hence, $-22.8 \%$ was regarded as the most reflective of phytoplankton leaves, with mean values that ranged from $7.2( \pm 0.2)$ to $8.3( \pm 0.3)$ (Table 1$)$.

\section{Carbon isotopic ratios of animals}

The 14 selected zooplankton taxa had mean $\delta^{13} \mathrm{C}$ values ranging from $-23.4 \%$ for chaetognaths in mid-estuary (SK1) to $-15.15 \%$ o for porcellanid zoeae in inshore waters (NS4) (Table 1). All zooplankton taxa were $\delta^{13} \mathrm{C}$-enriched relative to phytoplankton at SK3, except for chaetognaths $(-23.4 \%)$ at SK1. The

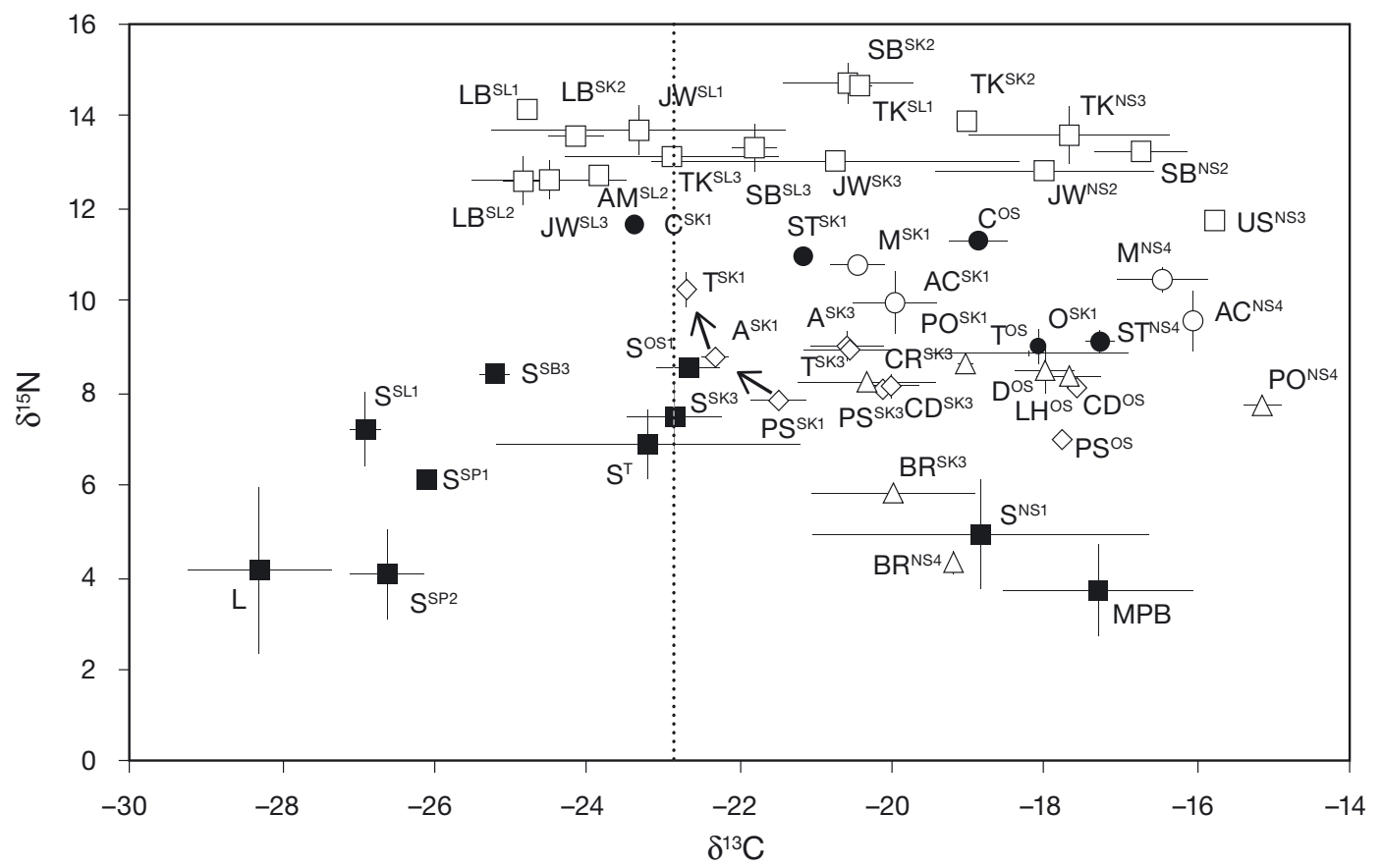

Fig. 2. Plots of unadjusted $\delta^{13} \mathrm{C}$ and $\delta^{15} \mathrm{~N}$ values of various primary producers, zooplankton and fish in Matang mangrove estuaries and adjacent coastal waters. Primary producers ( $\bullet$ ): L = senescent mangrove leaves, $\mathrm{S}=$ seston, $\mathrm{MPB}=$ microphytobenthos (from Okamura et al. 2010). Consumers: copepods $(\diamond), \mathrm{A}=$ Acartia spinicauda, $\mathrm{CD}=$ Centropages dorsispinatus, PS $=$ Pseudodiaptomus spp., T = Tortanus spp.; decapods $(\Delta), \mathrm{BR}=$ brachyuran zoeae, $\mathrm{CR}=$ caridean zoeae, $\mathrm{D}=$ diogenid zoeae, $\mathrm{LH}$ $=$ Lucifer hanseni, $\mathrm{PO}=$ Porcellanidae zoeae; hyperbenthic shrimps $(\mathrm{O}), \mathrm{AC}=$ Acetes spp., $\mathrm{M}=\mathrm{Mysidae}$; other zooplankton $(\bullet)$, $\mathrm{C}=$ Chaetognatha, $\mathrm{O}=$ Ostracoda, $\mathrm{ST}=$ Stomatopoda larvae; fish ( $\square$ ), AM = Arius maculatus, LB = Leiognathus brevirostis, $\mathrm{JW}$ = Johnius weberi, $\mathrm{SB}=$ Stolephorus baganensis, TK = Thryssa kammalensis, US = Upeneus sulphureus. Superscripts indicate stations, see Fig. 1, except T which indicates data for the lower estuary of SK, from Okamura et al. (2012). Dashed vertical line indicates phytoplankton $\delta^{13} \mathrm{C}$ value, error bars indicate $\pm \mathrm{SD}$, arrows indicate change in trophic position ( $\delta^{15} \mathrm{~N}$ values) of herbivorous (PS) through omnivorous (A) to carnivorous (T) copepods 
Table 3. Results of Kruskal-Wallis test on mean $( \pm \mathrm{SD})$ zooplankton $\delta^{13} \mathrm{C}$ values, with comparisons among stations. Zooplankton data were pooled based on their trophic positions. n: sample size; $H$ : Kruskal-Wallis test statistic; stations, see Fig. 1

\begin{tabular}{|lccccc|}
\hline Station & $\mathrm{n}$ & Mean & $\mathrm{SD}$ & $H$ & $\mathrm{p}$-level \\
\hline \multicolumn{5}{l}{ Herbivores } & and omnivores \\
SK1 & 9 & -20.1 & 1.8 & 18.7 & $<0.001$ \\
SK3 & 8 & -20.3 & 0.5 & & \\
NS4 & 3 & -15.1 & 0.2 & & \\
OS & 9 & -17.7 & 0.3 & & \\
Carnivores & & & & & \\
SK1 & 11 & -21.7 & 1.4 & 18 & $<0.001$ \\
SK3 & 2 & -20.6 & 0.6 & & \\
NS4 & 6 & -16.6 & 0.6 & & \\
OS & 4 & -18.5 & 0.5 & & \\
\hline
\end{tabular}

remaining taxa at Stn SK1 were enriched in $\delta^{13} \mathrm{C}$ relative to phytoplankton by 0.1 to $4.7 \%$.

At SK3, the zooplankton had $\delta^{13} \mathrm{C}$ values that fell within a narrow range of -21 to $-20 \%$, showing little evidence of mangrove carbon in their tissues (Table 1, Fig. 2). Similarly, nearshore zooplankton were more enriched in $\delta^{13} \mathrm{C}$ compared to phytoplankton, with mean $\delta^{13} \mathrm{C}$ values that ranged from $-19.2 \%$ for brachyuran zoeae to $-15.1 \%$ for porcellanid zoeae (Table 1, Fig. 2). Zooplankton collected at the offshore station, OS, had mean $\delta^{13} \mathrm{C}$ values of between -18.9 and $-17.6 \%$ (mean $\pm \mathrm{SD}=-18.0 \pm 0.5 \%$ ) (Fig. 2). After pooling the data, the $\delta^{13} \mathrm{C}$ value of zooplankton was found to be most enriched at NS4 (Kruskal-Wallis test, $\mathrm{p}<0.01$; Table 3 ).

Juvenile or small-size fish of 5 abundant species, Arius maculatus, Johnius weberi, Leiognathus brevirostris, Stolephorus baganensis and Thryssa kammalensis, in Matang mangrove estuaries had mean $\delta^{13} \mathrm{C}$ values that ranged from -24.8 to $-16.7 \%$ o (Table 1). The leiognathid L. brevirostris had the most depleted $\delta^{13} \mathrm{C}$ values (ranging from -24.8 to $-24.1 \%$ ) among the selected fish species. The ariid A. maculatus was also depleted in ${ }^{13} \mathrm{C}$ relative to phytoplankton, with a mean $\delta^{13} \mathrm{C}$ value of $-23.84 \%$ $( \pm 0.05)$. Both species were more confined to estuarine waters. The sciaenid $J$. weberi had a wide range of $\delta^{13} \mathrm{C}$ values, ranging from the most depleted value $(-24.5 \pm 1.0 \%)$ at the upper reaches of the Selinsing River (SL1) to the most enriched value in nearshore waters $(-18 \pm 1.4 \%)$. The engraulids $S$. baganensis and $T$. kammalensis had $\delta^{13} \mathrm{C}$ values that ranged from $-22.9 \%$ o $( \pm 1.4)$ to $-16.73 \%$ o $( \pm 0.6)$. The coastal species Upeneus sulphureus found in nearshore waters had a mean $\delta^{13} \mathrm{C}$ value of $-15.77 \%$ $( \pm 0.09)$ (Table 1, Fig. 2).

\section{Nitrogen isotopic ratios of consumers and trophic levels}

Consumers showed $\delta^{15} \mathrm{~N}$ values that ranged from $4.3 \%$ o $( \pm 0.2)$ for brachyuran larvae to $14.7 \%$ o $( \pm 0.9)$ for the anchovy Stolephorus baganensis (Fig. 2). Excluding brachyuran larvae, the $\delta^{15} \mathrm{~N}$ values of all other zooplankton ranged from 7.0 to $11.7 \%$, with the lowest value belonging to the herbivore Pseudodiaptomus $(7.6 \pm 0.5 \%)$. Zooplankton in general constituted 2 trophic levels in the Matang food web (Table 4, see Fig. 2).

At the upper reaches of the Sangga Kecil River species of Pseudodiaptomus, Acartia and Tortanus represented zooplankton at successively higher trophic positions (see indicative arrows, Fig. 2). Other than Tortanus spp., the carnivorous zooplankton included chaetognaths, Acetes spp., mysids and stomatopod larvae. The $\delta^{15} \mathrm{~N}$ values of carnivorous zooplankton ranged from 8.9 to $11.7 \%$, with a mean of $10.2 \%$ o $( \pm 1)$ (Fig. 2). Decapod larvae, adult Lucifer hanseni, the copepod Centropages dorsispinatus and ostracods had $\delta^{15} \mathrm{~N}$ values that ranged from 7.7 to $8.9 \%$, suggesting that these taxa were omnivorous. Omnivorous zooplankton had an overall mean $\delta^{15} \mathrm{~N}$ value of $8.4 \%$ ( \pm 0.4$)$, closer to Pseudodiaptomus spp. than to carnivorous zooplankton.

The 6 fish species had greater $\delta^{15} \mathrm{~N}$ values than those of zooplankton, ranging from 11.73 to $14.72 \%$. The mean $\delta^{15} \mathrm{~N}$ value of all fish combined $(13.3 \pm$ $0.8 \%$ ) was 3.1 and $5.7 \%$ higher than the carnivorous and herbivorous zooplankton, respectively (Fig. 2). This is in agreement with the $\delta^{15} \mathrm{~N}$ fractionation per trophic level as suggested in previous studies (Peterson \& Fry 1987).

\section{Seston composition}

The seston $(<63 \mu \mathrm{m})$ samples collected from the upper estuary at SP1 and SL1 and from the river mouth at SB3 were dominated by aggregated diatoms (mainly Thalassiosira sp.) which accounted for $>50 \%$ of the composition by volume (Table 5 ). Non-aggregated phytoplankton (mainly Coscinodiscus and Skeletonema species) and undefined organic material (with associated microorganisms including bacteria and fungi) constituted 13 to $26 \%$ and 2 to $24 \%$ of the seston, respectively. Ciliates and dinoflagellates were comparatively fewer than other seston components, with mean volumetric composition of $<2 \%$. It is of interest to note that the seston collected at SB3, which was comprised largely of aggregated 
Table 4. Trophic position of zooplankton (except brachyuran zoeae), fish and penaeid prawns from various studies conducted in Matang mangrove estuaries and adjacent coastal waters. Pseudodiaptomus spp. was assigned as baseline representative at the second trophic level

\begin{tabular}{|c|c|c|c|c|}
\hline Taxon & Mean $\delta^{15} \mathrm{~N}$ & $\begin{array}{l}\text { Estimated } \\
\text { isotopic tro- } \\
\text { phic position }\end{array}$ & $\begin{array}{l}\text { General trophic level } \\
\text { assigned in the } \\
\text { Matang food web }\end{array}$ & Source \\
\hline \multicolumn{5}{|l|}{ Zooplankton } \\
\hline \multicolumn{5}{|l|}{ Herbivore and omnivores } \\
\hline Pseudodiaptomus spp. & 7.6 & 2.0 & 2 & Present study \\
\hline Centropages dorsispinatus & 8.1 & 2.2 & 2 & Present study \\
\hline Porcellanidae zoeae & 8.2 & 2.2 & 2 & Present study \\
\hline Caridean zoeae & 8.2 & 2.2 & 2 & Present study \\
\hline Lucifer hanseni & 8.4 & 2.2 & 2 & Present study \\
\hline Diogenidae zoeae & 8.5 & 2.3 & 2 & Present study \\
\hline Ostracoda & 8.9 & 2.4 & 2 & Present study \\
\hline Acartia spinicauda & 8.9 & 2.4 & 2 & Present study \\
\hline \multicolumn{5}{|l|}{ Carnivores } \\
\hline Tortanus spp. & 9.6 & 2.7 & 3 & Present study \\
\hline Acetes spp. & 9.8 & 2.7 & 3 & Present study \\
\hline Stomatopoda larvae & 10.0 & 2.8 & 3 & Present study \\
\hline Mysidae & 10.6 & 3.0 & 3 & Present study \\
\hline Chaetognatha & 11.5 & 3.3 & 3 & Present study \\
\hline \multicolumn{5}{|l|}{ Fish larvae } \\
\hline Carangidae & 7.2 & 1.9 & 2 & Ooi (2011) \\
\hline Engraulidae & 8.8 & 2.4 & 2 & Ooi (2011) \\
\hline Carangidae 1 & 10.8 & 3.0 & 3 & Ooi (2011) \\
\hline Gobiidae & 11.1 & 3.2 & 3 & Ooi (2011) \\
\hline Engraulidae 1 & 11.5 & 3.3 & 3 & Ooi (2011) \\
\hline Blenidae & 12.0 & 3.5 & 3 & Ooi (2011) \\
\hline \multicolumn{5}{|l|}{ Juvenile and small-sized fish } \\
\hline Liza melinoptera & 9.5 & 2.6 & 3 & Then (2008) \\
\hline Anodontostoma chacunda & 9.7 & 2.7 & 3 & Hayase et al. (1999) \\
\hline Scathophagus argus & 10.8 & 3.1 & 3 & Then (2008) \\
\hline Upeneus sulphureus & 11.7 & 3.4 & 3 & Present study \\
\hline Ambassis gymnocephalus & 11.7 & 3.4 & 3 & Hayase et al. (1999) \\
\hline Plotosus canius & 11.9 & 3.4 & 3 & Then (2008) \\
\hline Lutjanus vitta & 11.9 & 3.4 & 3 & Hayase et al. (1999) \\
\hline Pomadasys kaakan & 12.1 & 3.5 & 3 & Then (2008) \\
\hline Tetraodon fluviatilis & 12.6 & 3.7 & 4 & Then (2008) \\
\hline Arius maculatus & 13.0 & 3.8 & 4 & Then (2008), present study \\
\hline Johnius weberi & 13.0 & 3.8 & 4 & Present study \\
\hline Johnius borneensis & 13.2 & 3.8 & 4 & Then (2008), Hayase et al. (1999) \\
\hline Leiognathus brevirostris & 13.4 & 3.9 & 4 & Present study \\
\hline Stolephorus insularis & 13.5 & 3.9 & 4 & Hayase et al. (1999) \\
\hline Lutjanus johnii & 13.6 & 4.0 & 4 & Then (2008) \\
\hline Stolephorus commersonii & 13.6 & 4.0 & 4 & Hayase et al. (1999) \\
\hline Stolephorus baganenesis & 13.8 & 4.0 & 4 & Present study \\
\hline Thryssa kammalensis & 13.9 & 4.1 & 4 & Then (2008), present study \\
\hline Epinephelus coioides & 14.5 & 4.3 & 4 & Then (2008) \\
\hline Thryssa hamiltonii & 14.6 & 4.3 & 4 & Then (2008) \\
\hline \multicolumn{5}{|l|}{ Juvenile penaeid prawns } \\
\hline Parapenaeopsis hardwickii & 8.4 & 2.3 & 2 & Chong et al. (2001) \\
\hline Parapenaeopsis sculptilis & 9.5 & 2.6 & 3 & Chong et al. (2001) \\
\hline Metapenaeus brevicornis & 9.7 & 2.7 & 3 & Chong et al. (2001) \\
\hline Penaeu merguinensis & 9.9 & 2.8 & 3 & Chong et al. (2001) \\
\hline Parapenaeopsis coromandelica & 10.3 & 2.9 & 3 & Chong et al. (2001) \\
\hline Metapenaeus lysianassa & 10.4 & 2.9 & 3 & Chong et al. (2001) \\
\hline
\end{tabular}


Table 5. Volumetric composition (\%) of seston components collected at 3 different stations in Matang mangrove estuaries. Data are means $( \pm \mathrm{SD})$. Stations, see Fig. 1

\begin{tabular}{|llccc|}
\hline \multirow{2}{*}{ Seston items } & \multicolumn{4}{c}{ Station } \\
& & SP1 & SL1 & SB3 \\
\hline \multirow{2}{*}{ Aggregated diatoms } & Mean & 59.4 & 50.1 & 83.2 \\
& SD & 8.3 & 9.6 & 2.0 \\
Non-aggregated phytoplankton & Mean & 18.3 & 26.4 & 13.3 \\
& SD & 1.1 & 5.3 & 3.6 \\
Ciliates/dinoflagellates & Mean & 0.8 & 0.2 & 1.3 \\
Undefined detrital material & SD & 0.2 & 0.02 & 0.3 \\
& Mean & 21.6 & 23.3 & 2.2 \\
& SD & 9.7 & 14.9 & 1.3 \\
& & & & \\
& & &
\end{tabular}

diatoms $(>80 \%)$ and undefined organic material (ca. $2 \%$ ), had a correspondingly depleted $\delta^{13} \mathrm{C}$ value $(-25.2 \pm 0.2 \%)$ which was closer to that of the upper estuary stations at SP1, SP2 and SL1, as compared to seaward stations at SK3, NS1 and OS1 (see Table 1). The aggregated diatom cells were invested with mucilage or extracellular polymeric substances (EPS) (sensu Thornton 2002) with adhering inorganic and organic particulates observable under the light microscope (Fig. 3a). The EPS, stained blue with Alcian Blue $\mathrm{pH} 2.5$ indicating mucopolysaccharides, and most of the organic particulates adhered could be removed by either hydrogen peroxide or dichromic acid treatment. Under SEM, the untreated diatom cells were often profusely covered by these particulates which were bound with the EPS and appeared as flakes (Fig. 3b,c).

\section{Dietary preference and frequency of occurrence of small fishes}

The relative importance of food items is captured by the PCA ordination biplot (Fig. 4). The factor loadings or eigenvectors indicate that the first 2 axes derived from PCA explained approximately $44 \%$ of the total variance of the dietary data. The first axis depicts increasing consumption of the prey items, Acetes spp., mysids and unidentified prawns, in a negative direction, while the consumption of detritus becomes increasingly important in a positive direction. On the second axis, increasing consumption, especially of the copepods Pseudodiaptomus annandalei and $P$. trihamatus, is in a negative direction.

The PCA biplot defines 4 major groups of consumers among juvenile fishes, namely: (1) the herbivore-detritivores or iliophagous feeders in the first quadrant, (2) the decapods and peracarid feeders in the second quadrant, (3) the copepod and holoplankton feeders in the fourth quadrant, and (4) the mixed feeders, centred around the origin of the biplot.

The ambassid Ambassis gymnocephalus, the ariid Arius maculatus, the leiognathids Leiognathus brevirostris and Eubleekeria splendens, and the engraulids Stolephorus baganensis and Thryssa kammalensis fed largely on copepods (Fig. 4), with a mean volumetric composition that ranged from 40 to $83 \%$ and an occurrence of 57 to $95 \%$. The most important copepod species, Pseudodiaptomus annandalei, was mainly consumed by juvenile ariids $A$. maculatus (85\% occurrence) and Arius venosus (68\%), all juvenile sciaenids (22 to $52 \%$ ) except Pennahia anea, engraulids (35 to $39 \%$ ) and leiognathids (34 to $75 \%$ ). The congener of Pseudodiaptomus annandalei, Pseudodiaptomus trihamatus, was also frequently consumed by $A$. maculatus with $>50 \%$ of occurrence. The dominant mangrove copepod species Acartia spinicauda, Parvocalanus crassirostris and Oithona spp. were observed in the diets of the ambassid, engraulids and leiognathids, but their contributions never exceeded $10 \%$ of the mean volumetric composition. Other copepod species, Calanopia thompsoni, Labidocera pectinata, Tortanus barbatus and Euterpina acutifrons, were rarely encountered and not ingested by most of the fish species. The benthic harpacticoids, however, constituted a considerable volume of the diet of the gerreid Gerres erythrourus and leiognathids, with a mean volumetric composition that ranged from 10 to $30 \%$ and an occurrence of 42 to $63 \%$. Chaetognaths and cirripede larvae were consumed in considerable amounts by the clupeid Ilisha melastoma, the gerreid G. erythrourus and the leiognathid Eubleekeria splendens, with volumetric compositions that ranged from 12 to $26 \%$.

Sergestid shrimps (Acetes spp.) were the major source of food after copepods, being consumed by various economically important or common fish species such as carangid, threadfin, snapper, grunter, anchovies, sciaenids and gobiids (Fig. 4), with mean volumetric composition ranging from 7 to $60 \%$ and occurrence of 9 to $61 \%$. Mysids were mainly eaten by the clupeid Ilisha melastoma, sciaenid Pennahia anea, mullid Upeneus sulphureus and gobiid Glossogobius giuris. Four fish species, Lutjanus johnii, Eleutheronema tetradactylum, $P$. anea and a carangid species, did not feed on copepods, but all 4 relied on hyperbenthic shrimps, while 1 species, Butis koilomatodon, fed on large quantities of amphipods (58\% by volume) and to a lesser extent isopods $(15 \%)$. 


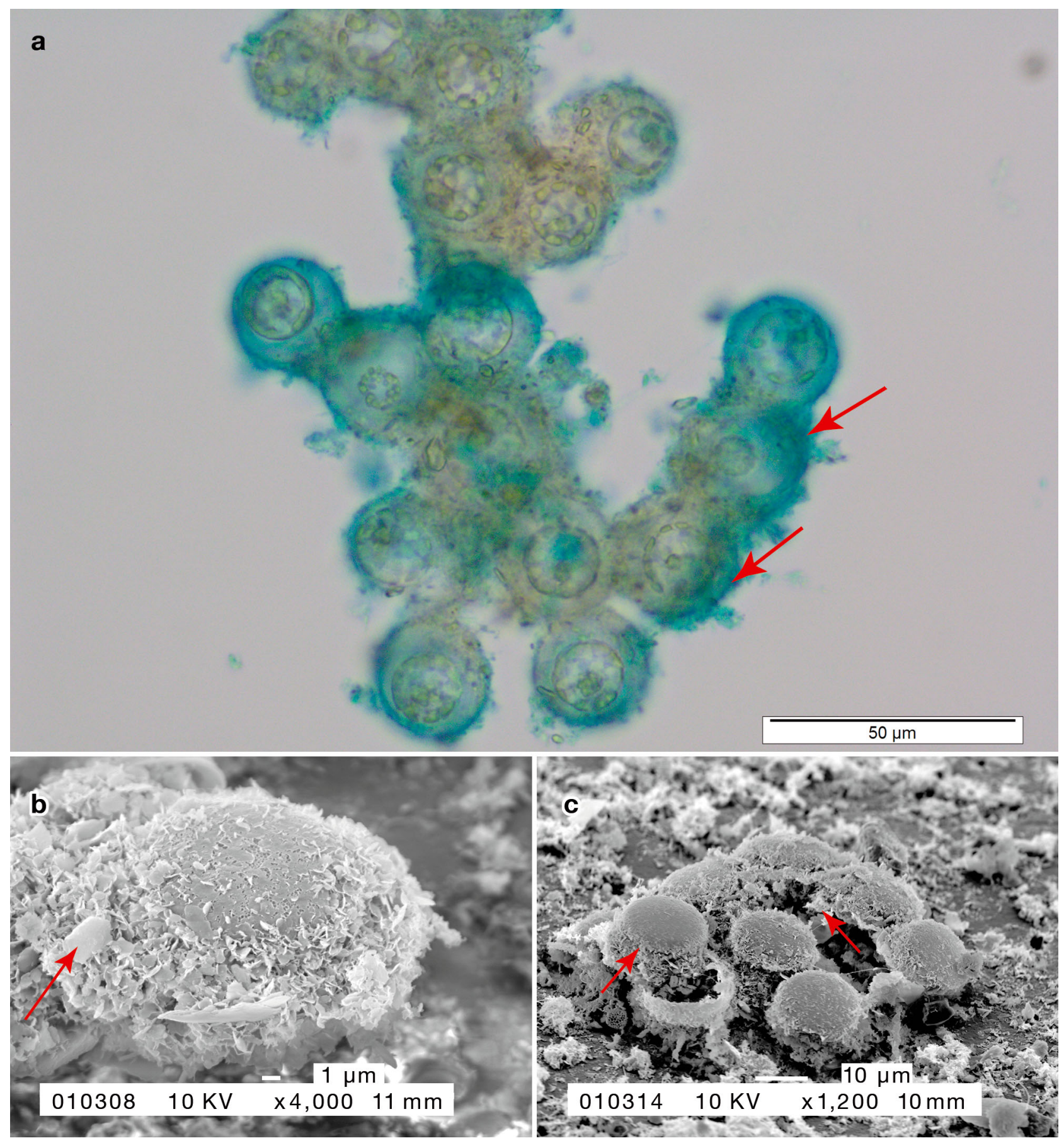

Fig. 3. Photomicrographs of aggregated or mucilage-secreting diatoms in the seston, viewed under (a) light microscope and $(\mathrm{b}, \mathrm{c})$ scanning electron microscope. Arrows in (a) indicate secretion of extracellular polymer substances (EPS) binding $(b, c)$ inorganic and organic particulates that appear as flaky peel offs

Only 3 species examined constituted the herbivoredetritivore group. These were Scatophagus argus, Ketengus typus and Anodontostoma chacunda which had $<5 \%$ occurrence of copepod food, did not feed on pelagic shrimps, but fed mainly on mangrove detritus and/or benthic microalgae (Fig. 4). The mixed feeders, including the ariids Arius venosus and Cryptarius truncatus, the clupeid Ilisha melastoma, the gerreids Gerres erythrourus and Gerres filamentous, the gobiid Glossogobius giuris, and all sciaenids (except Pennahia anea), fed considerably on copepods which constituted 8 to $37 \%$ by volume and 22 to $72 \%$ by frequency. 


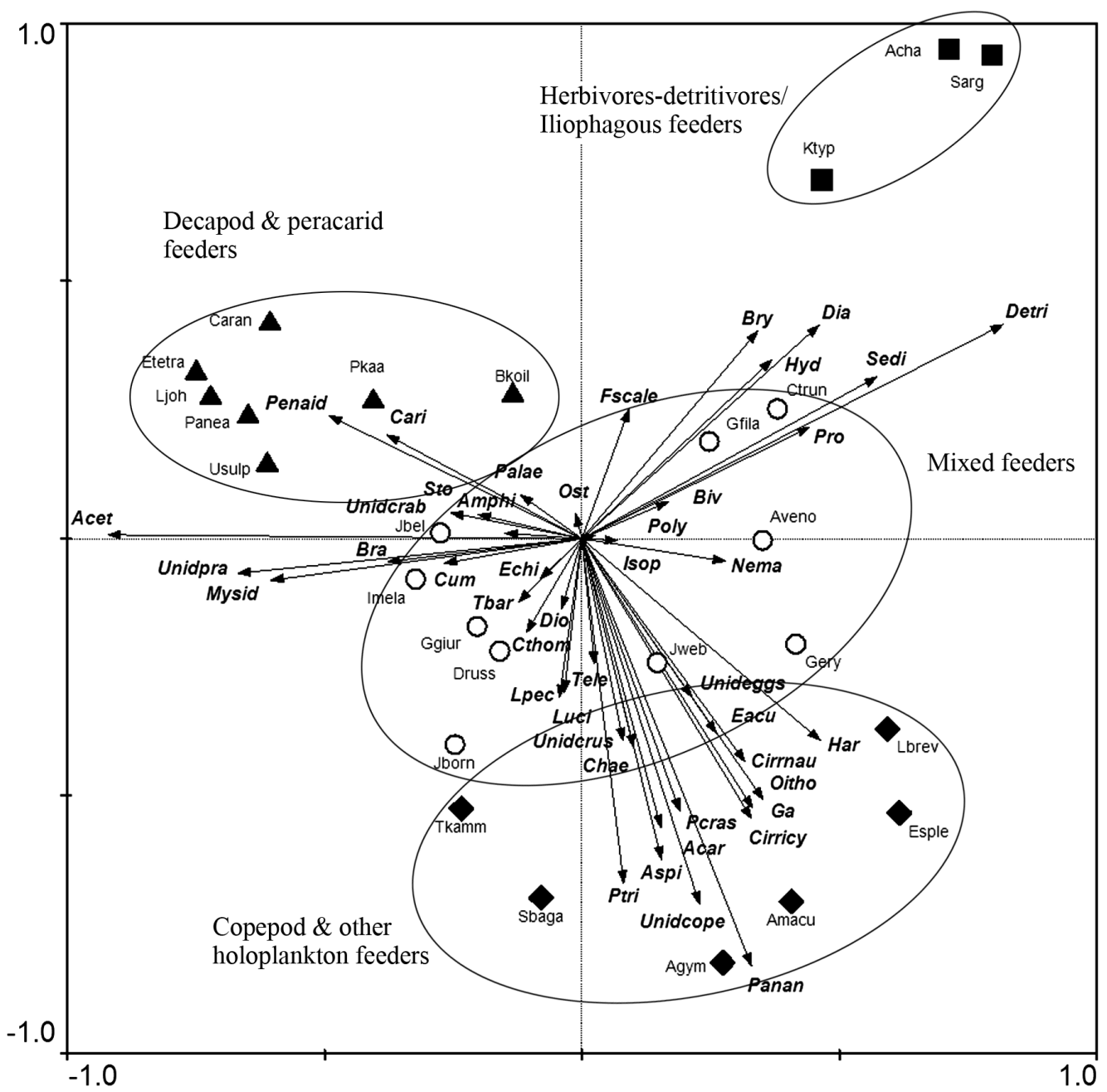

Fig. 4. Principal component biplots based on the dietary composition of 26 species of juvenile and small-sized fish found in Matang mangrove estuaries. Arrows denote food items, symbols denote fish feeding guilds as circled. Acar: Acartia sp.; Aspi: Acartia spinicauda; Pcras: Parvocalanus crassirostris; Panan: Pseudodiaptomus annandalei; Ptri: Pseudodiaptomus trihamatus; Cthom: Calanopia thompsoni; Lpec: Labidocera pectinata; Tbarb: Tortanus barbatus; Oitho: Oithona spp.; Eacu: Euterpina acutifrons; Har: harpacticoid; Unidcope: unidentified copepods; Cirrnau: cirripede nauplius; Cirricy: cirripede cypris; Mysid: Mysidae; Acet: Acetes spp.; Luci: Lucifer hanseni; Cari: caridean prawn; Palae: Palaemonidae prawn; Penaid: Penaeidae prawn; Bra: Brachyura crab; Dio: Diogenidae; Unidpra: unidentified prawn fragments; Unidcrab: unidentified crab fragments; Sto: Stomatopoda; Amphi: Amphipoda; Isop: Isopoda; Ost: Ostracoda; Cum: Cumacea: Unidcrust: unidentied crustacean fragments: Chae: Chaetognatha: Poly: Polychaeta: Ga: Gastropoda: Biv: Bivalvia: Echi: Echinodermata: Pro: Protozoa: Hyd: Hydrozoa: Bry: Bryozoa: Nema: Nematoda: Tele: Teleost: Fscale: fish scales: Unideggs: unidentified eggs: Dia: diatom: Detri: detritus: Sedi: sediment: Agym: Ambassis gymnocephalus: Amac: Arius maculatus: Ctrun: Cryptarius truncatus: Aveno: Arius venosus: Ktyp: Ketengus typus: Caran: Carangidae sp.: Acha: Anodontostoma chacunda: Imela: Ilisha melastoma: Bkoil: Butis koilomatodon: Sbaga: Stolephorus baganensis: Tkamm: Thryssa kammalensis: Gery: Gerres erythrourus: Gfila: Gerres filamentosus: Ggiur: Glossogobius giuris: Pkaa: Pomadasys kaakan: Lbrev: Leiognathus brevirostris: Espl: Eubleekeria splendens: Ljoh: Lutjanus johnii: Usulp: Upeneus sulphureus: Etetra: Eleutheronema tetradactylum: Sarg: Scatophagus argus: Druss: Dendrophysa russelii: Jborn: Johnius borneensis: Jbel: Johnius belangerii: Jweb: Johnius weberi: Panea: Pennahia anea.

\section{Contribution of primary sources to Matang food web}

The SIAR results indicate high dependency of zooplankton on phytoplankton inside mangrove estuaries, with phytoplankton contributing between 70 and $84 \%$ (median $=77 \%$; Fig. 5a). Phytoplankton contribution decreased towards the river mouth $(59 \%)$ and adjacent nearshore waters (46\%) where benthic diatoms were equally important (52\%). Zooplankton nutrition derived from the mangrove source appeared to be low in mangrove and adjacent coastal waters, with a source contribution of $<11 \%$. Phytoplankton also constituted the major source for small nekton in the mangrove estuaries, while phytoplank- 
(a) Zooplankton
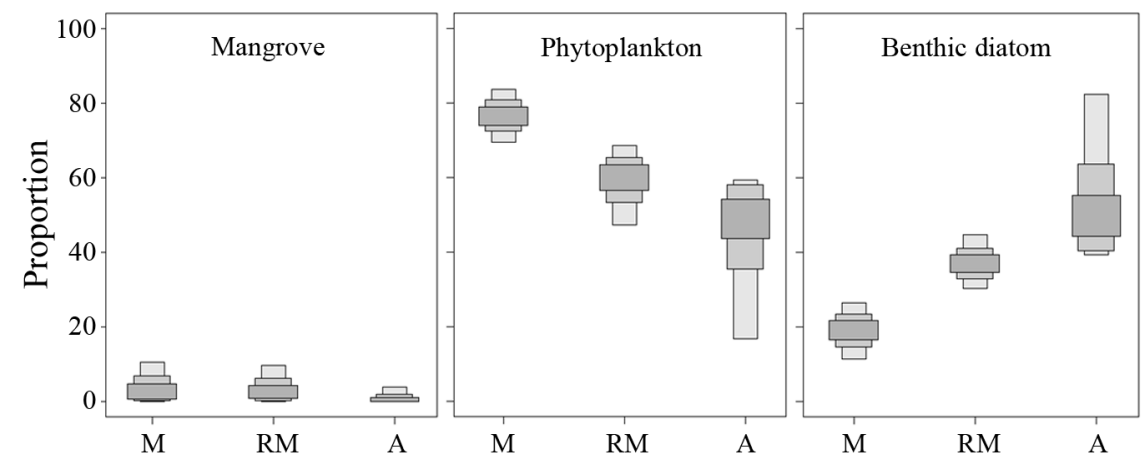

(b) Fish
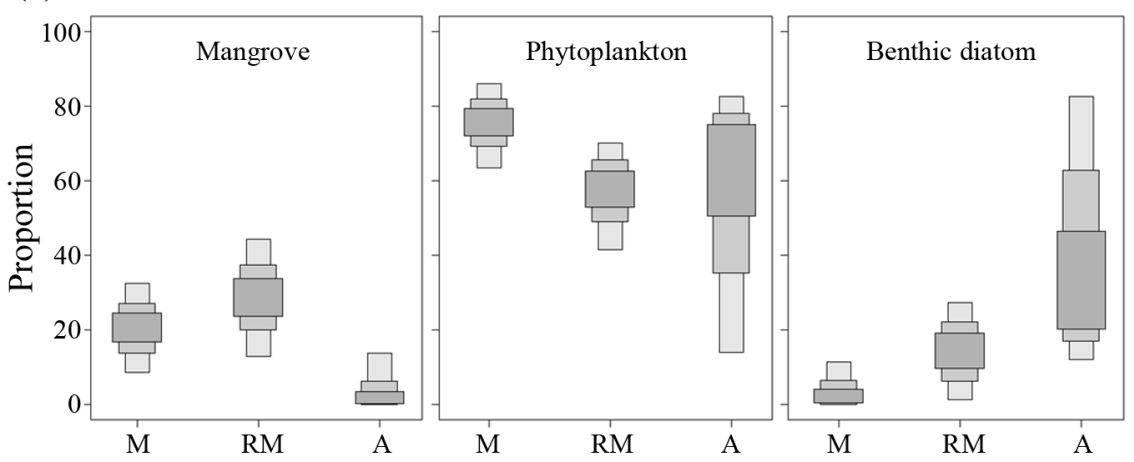

Fig. 5. Proportional contribution of primary producers to (a) zooplankton and (b) small nekton in the mangrove estuaries (M), river mouths (RM) and adjacent coastal waters (A), as determined by Stable Isotope Analysis in R. Bars indicate 25, 75 and $95 \%$ Bayesian confidence intervals

ton and benthic diatoms were major contributors in adjacent coastal waters (Fig. 5b). However, 8 to $44 \%$ of fish nutrition could be derived from the mangrove source inside the estuaries.

\section{DISCUSSION}

\section{Feeding competency and habits}

Given the dominance of copepods, which has been found to be $47 \%$ of the zooplankton assemblage in Matang estuaries (Chew \& Chong 2011), and the present results, which show significant copepod consumption by young and small-sized fish, copepods must play an important role in mangrove trophodynamics. Chew \& Chong (2011) reported that copepod abundance was highest at nearshore waters (20311 ind. $\mathrm{m}^{-3}$ ), but decreased both upstream ( $7 \mathrm{~km}$ : 15572 ind. $\mathrm{m}^{-3}$ ) and offshore (16 km: 12330 ind. $\mathrm{m}^{-3}$ ). This gradient in zooplankton abundance appears to influence the spatial as well as temporal abundance of fish larvae in Matang (Ooi \& Chong 2011). The authors reported that while salinity, turbidity and zooplankton food were the major factors structuring the larval fish assemblage, the number of larval families was only 17 as against 53 fish families reported for Matang estuary. Obviously, only certain species enter the estuaries as larvae, while the majority enters as young juveniles. This finding suggests that the early fish larvae which enter the estuary must be able to search and feed on suitably sized zooplankton food, while those that enter as juveniles must be competent to feed on larger food items.

The present study demonstrates juvenile fish competency to exploit a variety of small and large food items in the mangrove estuary. Clearly, most of the common juvenile mangrove fish examined (85\%) fed on zooplankton albeit to a variable extent (Fig. 4). The only 4 species that did not feed on copepods consumed the larger hyperbenthic shrimps (Acetes spp. and mysids) which are planktonic at night. Although Acartia, Parvocalanus and Oithona species are predominant taxa in Matang mangrove estuaries (Chew \& Chong 2011), Pseudodiaptomus annandalei, a demersal species that makes nocturnal migration into surface water (Kouassi et al. 2001), was the preferred species ingested by most of the small fishes $(77 \%)$ in the estuary. The next preferred food item (up to $60 \%$ of occurrence) was represented by the 
abundant hyperbenthic shrimps (particularly Acetes spp.). Other occasionally abundant organisms consumed, such as amphipods, isopods and ostracods, indicate that estuarine fishes are opportunistic feeders.

\section{Potential carbon pathways}

The $\mathrm{C} / \mathrm{N}$ ratio of the seston provides useful insight into the relative contribution of both phytoplankton and terrestrial plant detritus as particulate organic matter (POM). Various studies have shown that there would be no significant contribution of terrestrial plant detritus in the seston if the latter's $\mathrm{C} / \mathrm{N}$ ratio is $<10$ (Rau et al. 1990), while a C/N ratio exceeding 12 indicates significant contribution by terrestrial plant detritus (Cifuentes et al. 1996). Therefore, all our samples of fine seston particles $(<63 \mu \mathrm{m})$ which had low $\mathrm{C} / \mathrm{N}$ ratios ranging from 7.7 to 8.3 (see Table 1) suggest significant phytoplankton contribution. However, the low $\mathrm{C} / \mathrm{N}$ ratio and the largely depleted $\delta^{13} \mathrm{C}$ signatures $(<-25 \%)$ of $\mathrm{POM}$ in the upper estuary (SP1, SP2 and SL1) and river mouth (SB3, 1 sample) are at odds. These paradoxically ${ }^{13} \mathrm{C}$-depleted signatures could be due to phytoplankton utilizing the lighter carbon isotope when the ambient dissolved inorganic carbon (DIC) pool becomes ${ }^{13} \mathrm{C}$-depleted as a result of microbial respiration during decomposition of mangrove detritus (Bouillon et al. 2000, 2004).

The present observation of diatoms secreting EPS and the adhering extraneous organic material may provide another explanation for the depleted $\delta^{13} \mathrm{C}$ values of seston if the adhering organic material is of mangrove origin. Thus, the variable occurrence and abundance of sticky diatoms and microheterotrophic organisms could explain the large spatial and temporal variation of seston $\delta^{13} \mathrm{C}$ values observed in the estuary (Okamura et al. 2012). Interestingly, similarly depleted $\delta^{13} \mathrm{C}$ and low $\mathrm{C} / \mathrm{N}$ values of fine POM were reported in several Australian mangrove creeks by Werry \& Lee (2005) which they, however, attributed to bacterioplankton. Alongi et al. (2003) pointed out that the low $\mathrm{C} / \mathrm{N}$ ratio in the Matang estuary, although indicating high-quality water column material, might result from sewage and aquaculture effluent released from the nearby village and fish farms. Thus, given the strong tidal exchanges and salt intrusions into the upper estuary of Matang, it seems that the effects of other factors on seston carbon signature are equivocal.

Based on worldwide literature, France (1995) obtained an average $\delta^{13} \mathrm{C}$ value of $-22 \%$ for marine phytoplankton and $-17 \%$ for benthic microalgae.
Our seston samples collected at the lower estuary and in far offshore water had $\delta^{13} \mathrm{C}$ values close to this average value for marine phytoplankton. Benthic microalgae in Matang mudflats had a mean value of $-17.3 \%$, but ranged from -18.5 to $-16.1 \%$ (Okamura et al. 2010). Nearshore seston had a mean $\delta^{13} \mathrm{C}$ value $(-18.8 \pm 2.2 \%)$ intermediate between marine phytoplankton and benthic microalgae, thus indicating a mixture of phytoplankton and benthic microalgae in shallow water.

All zooplankton taxa in the present study had $\delta^{13} \mathrm{C}$ values closer to phytoplankton or benthic microalgae, thus indicating that zooplankton in mangrove estuaries had higher selectivity for algal food over mangrove detritus. The present study shows a narrow range of $\delta^{13} \mathrm{C}$ values for zooplankton $(-23.4$ to $-15.1 \%$ ), but agrees with similar Malaysian studies (Rodelli et al. 1984, Newell et al. 1995, Chong et al. 2001) in that consumer $\delta^{13} \mathrm{C}$ values became increasingly more enriched in the offshore direction. Nevertheless, the range in zooplankton $\delta^{13} \mathrm{C}$ values indicates only $<2 \%$ o depletion, but as much as $7 \%$ o enrichment, relative to phytoplankton. The mixing model analysis indicates $>70 \%$ contribution by phytoplankton. Therefore, mangrove carbon assimilation by zooplankton in mangrove estuaries is very small $(<11 \%)$, while consumption of a mixture of phytoplankton and benthic microalgae in coastal waters is conceivable. Hence, the evidence supports the hypothesis that phytoplankton is the main carbon source for zooplankton species in the turbid water of Matang mangrove estuaries. Nevertheless, the aggregated diatoms did not appear to be grazed by herbivorous zooplankton, as has also been reported by other workers (Dutz et al. 2005).

Experimental studies support the food-selectivity hypothesis that zooplankton prefer phytoplankton over vascular plant detritus because the latter is less palatable and low in nutritional value (DeMott 1988). If so, the phytoplankton populations in turbid mangrove waters must be assumed to support the standing stock of zooplankton in Matang mangrove estuaries.

Young juvenile Arius maculatus, Leiognathus brevirostris and Johnius weberi from the Selinsing River and the upper reaches of the Sangga Kecil River had $\delta^{13} \mathrm{C}$ values intermediate between mangrove and typical marine phytoplankton (see Table 1); their feeding habits were independently substantiated by stomach content analysis (Table 5). Similarly, juvenile Pomadasys kaakan, Plotosus canius, Tetraodon fluviatilis, Ambassis gymnocephalus, Stolephorus commersonii and Stolephorus insularis (Hayase et al. 
1999, Then 2008), juvenile mangrove snapper Lutjanus johnii (Tanaka et al. 2011), as well as penaeid prawns (Chong et al. 2001), found in upper Matang mangrove estuaries also exhibited intermediate $\delta^{13} \mathrm{C}$ values. The above-mentioned authors concluded that these animals derived their energy source from both phytoplankton and mangrove plants, with higher dependency on mangrove carbon for those that reside in the upper estuary. As expected, fish samples collected in the lower estuary and nearshore waters showed higher dependency on phytoplankton and benthic microalgae, with Upeneus sulphureus having the most enriched $\delta^{13} \mathrm{C}$ value (see Table 1). This species feeds exclusively on Acetes spp. and mysids (see Fig. 1).

\section{Matang mangrove trophic levels}

The food web structure from primary producers to juvenile and small nekton in Matang waters consists of 4 trophic levels (Table 4). True piscivores or fish feeding exclusively on other fish were few in Matang (Then 2008) and not examined in this study. Nevertheless, their inclusion would rightfully increase the Matang mangrove food web to 5 trophic levels.

Most copepods and decapod larvae are considered omnivorous, showing the ability to feed on a mixture of phytoplankton and smaller zooplankton (Kleppel 1993, Schwamborn et al. 2002). The present study supports this contention since zooplankton taxa are mainly omnivores (trophic positions of $>2$ ). Chaetognaths that largely depend on copepods (Tönnesson \& Tiselius 2005) had a higher trophic level than copepods (see Table 4), as reported in other pelagic food webs (e.g. Richoux \& Froneman 2009). Although, gut analysis of mysids (Winkler et al. 2007) and Acetes shrimps (Chiou et al. 2005) revealed some degree of omnivorous feeding, the present study based on stable isotope analysis indicates that Acetes spp. and mysids are carnivorous at the third trophic level.

Larval and small-size fishes found in Matang and nearshore waters are at the second to fourth trophic levels, while penaeid prawns are at the second and third trophic levels (see Table 4). The prey food items consumed by fish and prawns are generally consistent with their trophic positions. There were no strict herbivores observed for the selected fish and prawns. Both the gizzard shad Anodontostoma chacunda and grey mullet Liza melinoptera, categorized as phytodetrivores, had $\delta^{15} \mathrm{~N}$ values fairly close to that of omnivorous zooplankton. Stomach content analysis revealed that animal food such as copepods and protozoans (forams and tintinnids) formed a part of their diet other than benthic diatoms (Then 2008).

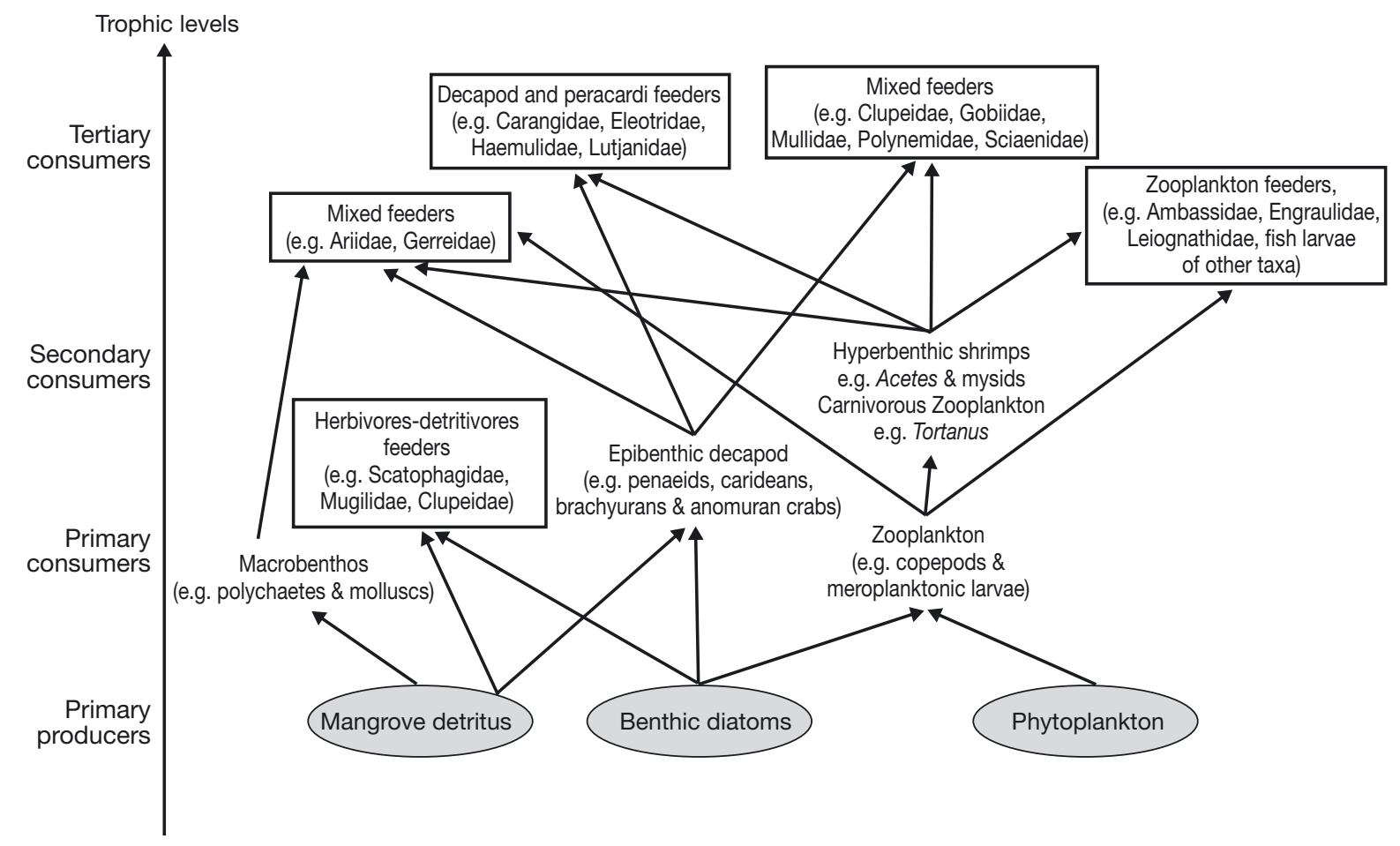

Fig. 6. Conceptual model of trophic pathways from primary producers to small nekton via zooplankton and other intermediaries in the Matang mangrove ecosystem. Boxes indicate main feeding guilds of fish larvae, juvenile and small-sized fish 
In general, fish at the higher trophic level have a larger size than those at lower trophic levels. Fish larvae in the same study area are at the second or third trophic level as compared to juvenile fish at the third and fourth trophic level. The engraulids, examined from larval to adult stage (different trophic levels), show an ontogenetic diet shift, with larvae relying on small plankton but switching to carnivory at the juvenile and adult stages.

\section{Implication of the present study}

Despite the high concentration of suspended mangrove detritus, the evidence from stable isotope analysis supports the hypothesis that phytoplankton and not mangrove detritus is the main carbon source for zooplankton nutrition in the turbid mangrove estuaries of Matang. High phytoplankton productivity is apparently not light-limited in the large open channels, nor is it limited by nutrients which are outwelled from the mangrove forests into the open channels (Tanaka \& Choo 2000). High phytoplankton biomass is attributed to the shallow depth and maintained by strong tidal vertical mixing particularly during spring tide.

This study shows that copepods and hyperbenthic shrimps (mysids and Acetes spp.) constitute the major food for juvenile and small-sized fishes in Matang mangrove estuaries. The ecological implication is that fish larvae and young juveniles that newly recruit into tropical mangrove estuaries can depend on the supply of crucial and preferred zooplankton food before they are physically competent to handle larger prey. Often as the larvae become larger, they become more adaptable to a variety of prey, including the macrobenthos that are nutritionally dependent on detritus and benthic microalgae. The increasing contribution of mangrove carbon to estuarine nekton as opposed to zooplankton (see Fig. 5) attests to this. Therefore, the multiple primary food sources to and the energy pathways emanating from zooplankton and benthic fauna into the mangrove food web are more complex than previously thought (Fig. 6).

Despite its usefulness, stable $\mathrm{C}$ and $\mathrm{N}$ isotope analysis appears unable to resolve the carbon source assimilated by consumers in the upper mangrove estuary and nearshore waters, where the contributions of phytoplankton and mangrove detritus or benthic microalgae are equivocal. Whether ${ }^{13} \mathrm{C}$-depleted DIC pools exist or play a major role in the upper estuarine water of Matang is unknown given the tidal ex- changes, anthropogenic impacts and population dynamics of microbial organisms. Further studies are required to elucidate this, especially the role of mucilage-secreting diatoms, bacteria and other microheterotrophs in the carbon pathway of turbid water mangrove estuaries.

Acknowledgements. We thank the Japan International Center for Agricultural Sciences (JIRCAS) and University of Malaya (UM) for funding this research, and UM for providing the research and logistical facilities. We acknowledge the Fisheries Department, Malaysia, for provision of a trawling permit. We are grateful to our skipper Mr. Lee Chee Heng and to Dr. Ooi Ai Lin for field assistance.

\section{LITERATURE CITED}

Alongi DM, Chong VC, Dixon P, Sasekumar A, Tirendi F (2003) The influence of fish cage aquaculture on pelagic carbon flow and water chemistry in tidally dominated mangrove estuaries of peninsular Malaysia. Mar Environ Res 55:313-333

Blaber SJM (2007) Mangroves and fishes: issues of diversity, dependence, and dogma. Bull Mar Sci 80:457-472

Blaber SJM, Blaber TG (1980) Factors affecting the distribution of juvenile estuarine and inshore fish. J Fish Biol 17: 143-162

> Bouillon S, Mohan PC, Sreenivas N, Dehairs F (2000) Sources of suspended organic matter and selective feeding by zooplankton in an estuarine mangrove ecosystem as traced by stable isotopes. Mar Ecol Prog Ser 208:79-92

Bouillon S, Koedam N, Baeyens W, Satyanarayana B, Dehairs F (2004) Selectivity of subtidal benthic invertebrate communities for local microalgal production in an estuarine mangrove ecosystem during the post-monsoon period. J Sea Res 51:133-144

Chew LL, Chong VC (2011) Copepod community structure and abundance in a tropical mangrove estuary, with comparisons to coastal waters. Hydrobiologia 666: 127-143

Chew LL, Chong VC, Hanamura Y (2007) How zooplankton are important to juvenile fish nutrition in mangrove ecosystems. In: Nakamura K (ed) JIRCAS Working Report 56. Japanese International Research Center for Agricultural Sciences, Tsukuba, Ibaraki, p 7-18

$>$ Chiou WD, Hwang JJ, Cheng LZ, Chen CT (2005) Food and feeding habit of Taiwan mauxia shrimp Acetes intermedius in the coastal waters of southwestern Taiwan. Fish Sci 71:361-366

Chong VC (1977) Studies on the small grey mullet Liza melinoptera (Valenciennes). J Fish Biol 11:293-308

Chong VC (2007) Mangroves-fisheries linkages-the Malaysian perspective. Bull Mar Sci 80:755-772

Chong VC, Low CB, Ichikawa T (2001) Contribution of mangrove detritus to juvenile prawn nutrition: a dual stable isotope study in a Malaysian mangrove forest. Mar Biol 138:77-86

Cifuentes LA, Coffin RB, Solorzano L, Cardenas W, Espinoza J, Twilley RR (1996) Isotopic and elemental variations of carbon and nitrogen in a mangrove estuary. Estuar Coast Shelf Sci 43:781-800 
DeMott WR (1988) Discrimination between algae and detritus by freshwater and marine zooplankton. Bull Mar Sci 43:486-499

> Dittel AI, Epifanio CE, Schwalm SM, Fantle MS, Fogel ML (2000) Carbon and nitrogen sources for juvenile blue crabs Callinectes sapidus in coastal wetlands. Mar Ecol Prog Ser 194:103-112

> Dutz J, Klein Breteler WCM, Kramer G (2005) Inhibition of copepod feeding by exudates and transparent exopolymer particle (TEP) derived from a Phaeocystis globosa dominated phytoplankton community. Harmful Algae 4: 929-940

- Edgar GJ, Shaw C (1995) The production and trophic ecology of shallow-water fish assemblages in southern Australia. II. Diets of fishes and trophic relationships between fishes and benthos at Western Port, Victoria. J Exp Mar Biol Ecol 194:83-106

Fleming M, Lin G, da Siveira L (1990) Influence of mangrove detritus in an estuarine ecosystem. Bull Mar Sci 47: 663-669

France RL (1995) Carbon-13 enrichment in benthic compared to planktonic algae: foodweb implications. Mar Ecol Prog Ser 124:307-312

Hayase S, Ichikawa T, Tanaka K (1999) Preliminary report on stable isotope ratio analysis for samples from Matang mangrove brackish water ecosystems. Jpn Agric Res Q 33:215-221

> Jacoby CA, Greenwood JG (1989) Emergent zooplankton in Moreton Bay, Queensland, Australia: seasonal, lunar, and diel patterns in emergence and distribution with respect to substrata. Mar Ecol Prog Ser 51:131-154

Kleppel GS (1993) On the diets of calanoid copepods. Mar Ecol Prog Ser 99:183-195

Kouassi E, Pagano M, Saint-Jean L, Arfi R, Bouvy M (2001) Vertical migrations and feeding rhythms of Acartia clausi and Pseudodiaptomus hessei (Copepoda: Calanoida) in a tropical lagoon (Ebrié, Côte d'Ivoire). Estuar Coast Shelf Sci 52:715-728

Laegdsgaard P, Johnson C (2001) Why do juvenile fish utilise mangrove habitats? J Exp Mar Biol Ecol 257: $229-253$

- Marguillier S, van der Velde G, Dehairs F, Hemminga MA, Rajagopal S (1997) Trophic relationships in an interlinked mangrove-seagrass ecosystem as traced by $\delta^{13} \mathrm{C}$ and $\delta^{15}$ N. Mar Ecol Prog Ser 151:115-121

> McCutchan JH, Lewis WM, Kendall C, McGrath CC (2003) Variation in trophic shift for stable isotope ratios of carbon, nitrogen, and sulfur. Oikos 102:378-390

McKinnon A, Klumpp D (1998) Mangrove zooplankton of North Queensland, Australia. II. Copepod egg production and diet. Hydrobiologia 362:145-160

Nagelkerken I, van der Velde G, Gorissen MW, Meijer GJ, Van't Hof T, den Hartog C (2000) Importance of mangroves, seagrass beds and the shallow coral reef as a nursery for important coral reef fishes, using a visual census technique. Estuar Coast Shelf Sci 51:31-44

National Hydrographic Center (2002) Tide tables Malaysia. Royal Malaysian Navy, Malaysia

Newell RIE, Marshall N, Sasekumar A, Chong VC (1995) Relative importance of benthic microalgae, phytoplankton, and mangroves as sources of nutrition for penaeid prawns and other coastal invertebrates from Malaysia. Mar Biol 123:595-606

Odum WE, Heald EJ (1975) The detritus-based food web of an estuarine mangrove community. In: Cronin LE (ed)
Estuarine research: chemistry, biology and the estuarine system. Academic Press, New York, NY, p 265-286

Okamura K, Tanaka K, Siow R, Man A, Kodama M, Ichikawa T (2010) Spring tide hypoxia with relation to chemical properties of the sediments in the Matang mangrove estuary, Malaysia. Jpn Agric Res Q 44:325-333

Okamura K, Tanaka K, Siow R, Man A, Kodama M, Ichikawa $\mathrm{T}$ (2012) Chemical properties of the surface sediments with relation to the hypoxia in the Matang mangrove estuary, Malaysia. In: Tanaka K (ed) JIRCAS Working Report 75, Japanese International Research Center for Agricultural Sciences, Tsukuba, Ibaroki, p 7-14

Ooi AL (2011) Assemblage, recruitment and ecology of fish larvae in Matang mangrove estuary and adjacent waters, Peninsular Malaysia. PhD thesis, University of Malaya, Kuala Lumpur

> Ooi AL, Chong VC (2011) Larval fish assemblages in a tropical mangrove estuary and adjacent coastal waters: offshore-inshore flux of marine and estuarine species. Cont Shelf Res 31:1599-1610

Parnell AC, Inger R, Bearhop S, Jackson AL (2010) Source partitioning using stable isotopes: coping with too much variation. PLoS ONE 5:1-5

Peterson BJ, Fry B (1987) Stable isotopes in ecosystem studies. Annu Rev Ecol Syst 18:293-320

Rau GH, Teyssie JL, Rassoulzadegan F, Fowler SW (1990) ${ }^{13} \mathrm{C} /{ }^{12} \mathrm{C}$ and ${ }^{15} \mathrm{~N} /{ }^{14} \mathrm{~N}$ variations among size-fractionated marine particles: implications for their origin and trophic relationships. Mar Ecol Prog Ser 59:33-38

> Richoux NB, Froneman PW (2009) Plankton trophodynamics at the subtropical convergence, Southern Ocean. J Plankton Res 31:1059-1073

Robertson AI, Blaber SJM (1992) Plankton, epibenthos and fish communities. In: Robertson AI, Alongi DM (eds) Coastal and estuarine studies 41, tropical mangrove ecosystems. American Geophysical Union, Washington, DC, p 173-224

> Robertson AI, Daniel PA (1989) The influence of crabs on litter processing in high intertidal mangrove forests in tropical Australia. Oecologia 78:191-198

Robertson AI, Alongi DM, Boto KG (1992) Food chains and carbon fluxes. In: Robertson AI, Alongi DM (eds) Coastal and estuarine studies 41, tropical mangrove ecosystems. American Geophysical Union, Washington, DC, p 293-326

Robertson A, Duke N (1987) Mangroves as nursery sites: comparisons of the abundance and species composition of fish and crustaceans in mangroves and other nearshore habitats in tropical Australia. Mar Biol 96:193-205

Robertson AI, Dixon P, Daniel PA (1988) Zooplankton dynamics in mangrove and other nearshore habitats in tropical Australia. Mar Ecol Prog Ser 43:139-150

> Rodelli MR, Gearing JN, Gearing PJ, Marshall N, Sasekumar A (1984) Stable isotope ratio as a tracer of mangrove carbon in Malaysian ecosystems. Oecologia 61:326-333

> Schwamborn R, Ekau W, Voss M, Saint-Paul U (2002) How important are mangroves as a carbon source for decapod crustacean larvae in a tropical estuary? Mar Ecol Prog Ser 229:195-205

> Schwamborn R, Ekau W, Silva A, Schwamborn S, Silva T, Neumann-Leitão S, Saint-Paul U (2006) Ingestion of large centric diatoms, mangrove detritus and zooplankton by zoeae of Aratus pisonii (Crustacea: Brachyura: Grapsidae). Hydrobiologia 560:1-13

Tanaka K, Choo PS (2000) Influences of nutrient outwelling 
from the mangrove swamp on the distribution of phytoplankton in the Matang mangrove estuary, Malaysia. J Oceanogr 56:69-78

Tanaka K, Hanamura Y, Chong VC, Watanabe S and others (2011) Stable isotope analysis reveals ontogenetic migration and the importance of a large mangrove estuary as a feeding ground for juvenile John's snapper Lutjanus johnii. Fish Sci 77:809-816

Then AYH (2008) The structure and trophodynamics of the fish community in estuaries of Matang mangrove forest reserve, Peninsular Malaysia. MSc thesis, University of Malaya, Kuala Lumpur

Thornton DACO (2002) Diatom aggregation in the sea: mechanisms and ecological implications. Eur J Phycol 37:149-161

Tönnesson K, Tiselius P (2005) Diet of the chaetognaths Sagitta setosa and $S$. elegans in relation to prey abun-

Editorial responsibility: Antonio Bode,

A Coruña, Spain dance and vertical distribution. Mar Ecol Prog Ser 289: $177-190$

Vander Zanden MJ, Rasmussen B (1999) Primary consumer $\delta^{13} \mathrm{C}$ and $\delta^{15} \mathrm{~N}$ and the trophic position of aquatic consumers. Ecology 80:1395-1401

Vander Zanden MJ, Rasmussen JB (2001) Variation in $\delta^{15} \mathrm{~N}$ and $\delta^{13} \mathrm{C}$ trophic fractionation: implications for aquatic food web studies. Limnol Oceanogr 46:2061-2066

Werry J, Lee SY (2005) Grapsid crabs mediate link between mangrove litter production and estuarine planktonic food chains. Mar Ecol Prog Ser 293:165-176

> Winkler G, Martineau C, Dodson JJ, Vincent WF, Johnson LE (2007) Trophic dynamics of two sympatric mysid species in an estuarine transition zone. Mar Ecol Prog Ser 332:171-187

Wolcott DL, O'Connor NJ (1992) Herbivory in crabs: adaptations and ecological considerations. Am Zool 32:370-381

Submitted: January 19, 2012; Accepted: August 24, 2012

Proofs received from author(s): November 11, 2012 